UNIVERSIDADE DE SÃO PAULO

ESCOLA DE ENFERMAGEM DE RIBEIRÃO PRETO

BIANCA CRISTINA CICCONE GIACON

Ajustamento familiar nos primeiros cinco anos de diagnóstico de esquizofrenia

Ribeirão Preto 


\title{
Ajustamento familiar nos primeiros cinco anos de diagnóstico de
}

\author{
esquizofrenia
}

Dissertação de mestrado apresentada à
Escola de Enfermagem de Ribeirão Preto da
Universidade de São Paulo para obtenção do
título de Mestre em Enfermagem em
Enfermagem Psiquiátrica.

Área de Concentração: Enfermagem Psiquiátrica - o doente, a doença e as práticas terapêuticas.

Orientadora: Prof $^{\mathrm{a}}$ Dr $^{\mathrm{a}}$ Sueli Aparecida Frari Galera

Ribeirão Preto 
AUTORIZO A REPRODUÇAO TOTAL OU PARCIAL DESTE TRABALHO, POR QUALQUER MEIO CONVENCIONAL OU ELETRÔNICO, PARA FINS DE ESTUDO E PESQUISA, DESDE QUE CITADA A FONTE.

\section{FICHA CATALOGRÁFICA}

Giacon, Bianca Cristina Ciccone Giacon

Ajustamento familiar nos primeiros cinco anos de diagnóstico de esquizofrenia. Ribeirão Preto, 2009.

82 f.; $30 \mathrm{~cm}$.

Dissertação apresentada à Escola de Enfermagem de Ribeirão Preto/USP Enfermagem Psiquiátrica - o doente, a doença e as práticas terapêuticas.

Orientador: Galera, Sueli Aparecida Frari

1. Esquizofrenia; 2. Enfermagem Psiquiátrica; 3. Família. 


\section{FOLHA DE APROVAÇÃO}

GIACON, B. C. C. Ajustamento familiar nos primeiros cinco anos de diagnóstico de esquizofrenia. Dissertação apresentada ao Departamento de Psiquiatria e Ciências Humanas da Escola de Enfermagem de Ribeirão Preto da Universidade de São Paulo para obtenção do título de Mestre em Enfermagem Psiquiátrica.

Dissertação de mestrado apresentada à Escola de Enfermagem de Ribeirão Preto da Universidade de São Paulo para obtenção do título de Mestre em Enfermagem em Enfermagem Psiquiátrica.

Área de Concentração: Enfermagem Psiquiátrica - o doente, a doença e as práticas terapêuticas.

Aprovado em:

Banca Examinadora

Prof. Dr. Instituição:

Julgamento: Assinatura:

Prof. Dr. Instituição:

Julgamento: Assinatura:

Prof. Dr. Instituição:

Julgamento: Assinatura: 


\section{DEDICATÓRIA}

À Deus, por ter me iluminado durante todo o caminho, por ter me dado paciência e força nos momentos mais difíceis, e por me proporcionar a alegria de ter pessoas especiais ao meu lado .

Aos meus pais, $\mathcal{N}$ orberto e Liliane, pelo amor que a mim dedicam, pela minha vida, minha educação, e a minha formação. Pelo incentivo constante do meu crescimento, pela aceitação de minhas escolhas, sendo elas certas ou erradas.

A minha querida irmã Lara, por sempre acreditar no meu melhor, por agüentar minhas ausências e momentos de dificuldades.

A minha querida tia Jú, por ter sido um exemplo a seguir, a incentivadora desse sonho, sempre presente, com seu amor e carinho. 


\section{Agradecimentos}

Aos meus avós, Alzira e Teleco, por tođo seu amor, presença e importância em minha vida.

Ao tio Gu, Dani, Gustavo, Ricardo por sempre me apoiarem e acreditarem no meu potencial

Ao meu amor, Fabio (Yoko), por estar ao meu lado em um dos anos mais difíceis da minha vida. Por agüentar minhas alterações de humor, pela compreensão dos momentos de dificuldades, pelo apoio quando me sentia fraca e pelo amor a mim dedicado.

À Profa $\operatorname{Dr}^{a}$ Sueli Aparecida Frari Galera, por sua competência, disponibilidade e sensibilidade na orientação deste trabalho e pela compreensão das minhas dificuldades. Por ter sido uma das pessoas principais no meu aprendizado e pela sua amizade durante todos esses anos.

À minhas amigas Carol e Leninha, pela ajuda no desenvolvimento do trabalho. Pela amizade estabelecida e presença nos principais momentos de dificuldade.

Á minha amiga Manu, que em seu sorriso, fez com que esse processo se tornasse mais alegre.

À todas as minhas amigas que moraram comigo nestes anos e aqueles amigos que estavam presente, por estarem sempre perto de mim quando me sentia sozinha, pelas lagrimas de desespero e longos telefonemas, $e$ principalmente, por entenderem minha ausência em muitos momentos.

À Lais pela contribuição em minha pesquisa, dedicação e esforço.

À todos os funcionários do SNúcleo de Saúde Mentale do Ambulatório, locais onde foram colhidos os dados.

À todas as famílias que dedicaram seu tempo para o desenvolvimento deste trabalho.

À CAPES, pelo apoio financeiro para o desenvolvimento desta pesquisa. 


\section{RESUMO}

GIACON, B.C.C. Ajustamento familiar nos primeiros cinco anos de diagnóstico de esquizofrenia. 2009. 82f. Dissertação (Mestrado) - Escola de Enfermagem de Ribeirão Preto, Universidade de São Paulo, Ribeirão Preto, 2009.

A esquizofrenia é um dos principais problemas de saúde pública da atualidade, causando grande sofrimento para o doente e sua família. Quando ocorre o primeiro episódio da doença, geralmente no final da adolescência, a família vive uma situação de estresse que desorganiza todo o grupo. A vida familiar é interrompida e a trajetória de vida pode ser modificada. Nos primeiros cinco anos de convivência com a doença mental, a família procura ajustar-se à nova situação. O objetivo deste trabalho foi identificar a trajetória de famílias nos primeiros cinco anos de convivência com a doença mental, descrevendo e interpretando o processo de ajustamento. O referencial teórico metodológico utilizado neste trabalho baseouse no Interacionismo Simbólico, na Abordagem Sistêmica da Família e na Teoria da Trajetória de vida. Foram entrevistados, no total, 23 familiares de 21 portadores de esquizofrenia, diagnosticados no máximo há cinco anos, que aceitaram a proposta de contar a história familiar após o adoecimento. A coleta de dados foi conduzida por uma entrevista com cada família. Os participantes foram esclarecidos quanto ao objetivo do estudo e assinaram o Termo de Consentimento Livre e Esclarecido. Foram realizadas 11 entrevistas no Núcleo de Saúde Mental do Centro de Saúde Escola e dez entrevistas no Ambulatório de Retorno da Enfermaria de Psiquiatria do HCRP, ambos os serviços da FMRP-USP. Elas foram gravadas em fita K7 e transcritas. O projeto foi encaminhado e aceito pelo Comitê de Ética em Pesquisa do HCRP-FMRP-USP. A análise das entrevistas foi realizada na proposta do método da Teoria fundamentada nos dados e visou determinar uma linha do tempo que permitiu descrever o processo de ajustamento, que pode ser descrito em três fases: percebendo a mudança, diagnóstico e início do tratamento e seguindo em frente. Quando o doente começa a apresentar mudanças de comportamento, como sinais e sintomas psicóticos, a família percebe que algo está errado, mas não tem a preocupação em procurar o serviço de saúde. Ela justifica como atitudes do processo de transição da fase infantil para a adulta. Após o primeiro episódio psicótico, ocorre um choque em todo o núcleo familiar. Sentimentos intensos são vivenciados. Após o estabelecimento do diagnóstico e o inicio do tratamento, ocorre uma melhora e a família vivencia sentimentos de esperança e medo. Esperança que o doente melhore e medo de uma nova crise como a vivenciada na fase anterior. Após os cinco primeiros anos a família segue em frente estimulando a independência e autonomia de seu doente e vigiando seus comportamentos. Concluímos, portanto, que todas as fases apresentadas neste projeto são ricas e podem ser mais exploradas. A confusão entre os sintomas iniciais do adoecimento e as características da adolescência, a dificuldade do diagnostico e o pouco apoio do sistema de saúde nos primeiros cinco anos. Talvez um apoio contínuo e educativo desde o inicio da doença diminua o impacto na família, suas transformações sejam mais amenas e ela consiga, assim, proporcionar se tornar um ambiente de qualidade para seus membros e seu doente.

Palavras-chaves: Esquizofrenia. Família. Enfermagem Psiquiátrica. 


\begin{abstract}
GIACON, B.C.C. Family adjustment in the first five years after the diagnosis of schizophrenia. 2009. 82f. Dissertação (Mestrado) - Escola de Enfermagem de Ribeirão Preto, Universidade de São Paulo, Ribeirão Preto, 2009.

Schizophrenia is a disease that causes great suffering for the patient and his family. The first episode of the disease appears more often in older teenagers, and when it occurs, the family goes through a situation of stress that disrupt the entire group. The family life course is interrupted and its trajectory can be modified. After the diagnosis of schizophrenia the family tries to adjust themselves in this new situation. The objective of this study was to identify the trajectory of the family in the first five years after the diagnosis of schizophrenia, describing and perceiving the adjustment process. This study is based in Symbolic Interactionism, Family Systemic Theory and Trajectory Life Theory. Interviews were made with 23 familiars from 21 patients diagnosed with schizophrenia. The gap between the diagnosis and the interview was no longer than 5 years, and the familiars accepted to tell the family history after the diagnosis. The study data was collected with an interview with a family member. The participants were given an explanation about the objectives of the study and signed a term that they were being part of this study by their own will, and in case of a negative answer the treatment wasn't going to change. Eleven interviews were taken in the Mental Health Nucleus of the School Health Center, and ten interviews were taken in the ambulatory of psychiatry in the HCRP. Both facilities belong to the FMRP-USP. The conversations were recorded in tapes and then transcribed. The project was sent and accepted by the Ethical Research Group. The interview analysis was made with the Fundament Theory and tried to determine a sequence in time that made possible to describe the adjustment process, which can be divided in 3 phases: perceiving the change, diagnosis and the initiation of treatment and the family restart. When the patient begin to present behavior changes, like psychotic signs and symptoms, the family knows that something is wrong but they don't search for a health facility. They think that the patient attitude is a common problem that happens in the transition of the teenage to adult life. After the first psychotic episode, there is a shock in the whole family. People go through intense feelings. After the diagnosis and the beginning of the treatment, the situation become a little better and the family start to have hope and fear. They hope that the patient gets better, and they fear another psychotic episode like the one experienced before. After the first five years, the family moves on, trying to stimulate the independence and the autonomy of the patient, but still paying attention to his behavior. All phases presented in this project are important and can be more studied. Other issues need more study too, like: the confusion between the initial symptoms and the adolescent characteristics, the difficult of the diagnosis and the lack of health system support in the first 5 years. Maybe a continuous and educative support since the beginning of the disease would diminish the impact in the family. With less transformation in the family circle it's more possible to create a healthy environment with quality of life for the patient and his family.
\end{abstract}

Descriptors: Schizophrenia. Family. Psychiatric Nursing. 


\section{RESUMEN}

GIACON, B.C.C. Ajustamiento familiar en los primeros cinco anos de diagnóstico de esquizofrenia. 2009. 82f. Dissertação (Mestrado) - Escola de Enfermagem de Ribeirão Preto, Universidade de São Paulo, Ribeirão Preto, 2009.

La esquizofrenia es uno de los principales problemas de salud pública de la actualidad, causando grande sufrimiento para el enfermo y su familia. Cuando ocurre el primer episodio de la enfermedad, generalmente en el final de la adolescencia, la familia vive una situación de estrés que desorganiza todo el grupo. La vida familiar es interrumpida y la trayectoria de vida puede ser modificada. En los primeros cinco años de convivencia con la enfermedad mental, la familia busca ajustarse a la nueva situación. El objetivo de este trabajo fue identificar la trayectoria de familias en los primeros cinco años de convivencia con la enfermedad mental, describiendo e interpretando el proceso de ajustamiento. El referencial teórico metodológico utilizado en este trabajo se basó en el Interaccionismo Simbólico, en el Abordaje Sistémico de la Familia y en la Teoría de la Trayectoria de vida. Fueron encuestados, en el total, 23 familiares de 21 portadores de esquizofrenia, diagnosticados desde hace cinco años, que aceptaron la propuesta de contar la historia familiar después de que surgió la enfermedad. La recolección de datos fue conducida por una encuesta realizada con cada familia. Los participantes fueron aclarados del objetivo del estudio y firmaron el Auto de Consentimiento Libre y Aclarada. Fueron realizadas 11 entrevistas en el Núcleo de Salud Mental del Centro de Salud Escuela y otras diez en el Ambulatorio de Retorno da la Enfermería de Psiquiatría del HCRP ${ }^{1}$, ambos servicios de la FMRP-USP ${ }^{2}$. Ellas fueron grabadas en cintas K7 y transcriptas. En proyecto fue encaminado y acepto por la Comisión de Ética en Investigación del HCRP-FMRP-USP. El análisis de las entrevistas fue realizada en la propuesta del método de la Teoría fundamentada en los datos y pretendió determinar una línea de tiempo que permitió describir el proceso de ajustamiento, que puede ser descrito en tres fases: percibiendo el cambio, diagnóstico e inicio del tratamiento y siguiendo adelante. Cuando el enfermo empieza a presentar cambios de comportamiento, como señal y síntomas psicóticos, la familia nota que algo está mal, pero no tiene la preocupación de buscar el servicio de salud. Ella justifica como actitudes del proceso de transición de la fase infantil para la adulta. Tras el primer episodio psicótico, ocurre un choque en todo en núcleo familiar. Sentimientos intensos son vividos. Después del establecimiento del diagnóstico y el inicio del tratamiento, ocurre una mejora y la familia vive sentimientos de esperanza y miedo. Esperanza que el enfermo mejore y miedo de una nueva crisis como la vivida en la fase anterior. Pasados los cinco primeros años la familia sigue adelante estimulando la independencia y autonomía de su enfermo y vigilando sus comportamientos. Concluimos, por lo tanto, que todas las fases presentadas en este proyecto son ricas y pueden seguir siendo investigadas. La confusión entre los primeros síntomas de la enfermedad y las características de la adolescencia, la dificultad del diagnóstico y la escasa asistencia del sistema de salud en los primeros cinco años. Tal vez un apoyo continuo y educativo desde el inicio de la enfermedad disminuya el impacto en la familia, sus transformaciones sean menos duras y ella consiga, así, propiciar o volverse un ambiente de cualidad para sus miembros y su enfermo.

Palabras clave: Esquizofrenia. Familia. Enfermería Psiquiátrica. 


\section{LISTA DE ABREVEATURAS E SIGLAS}

CSE - Centro de Saúde Escola

HCRP - Hospital das Clínicas de Ribeirão Preto

FMRP - Faculdade de Medicina de Ribeirão Preto

USP - Universidade de São Paulo 
INTRODUÇÃO E REVISÃO DE LITERATURA .................................................11

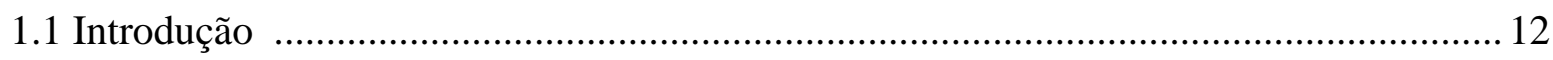

$1.2 \mathrm{O}$ ajustamento familiar frente à doença mental ..................................................... 14

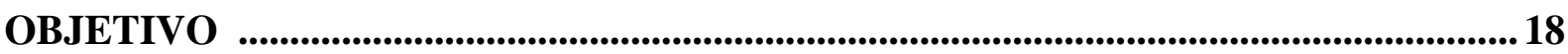

REFERENCIAL TEÓRICO METODOLÓGICO .......................................................... 20

3.1 Referencial Teórico Metodológico …......................................................................... 21

PERCURSO METODOLÓGICO _................................................................................ 25

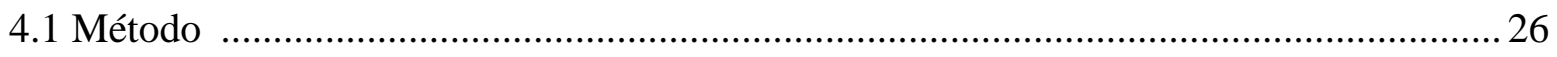

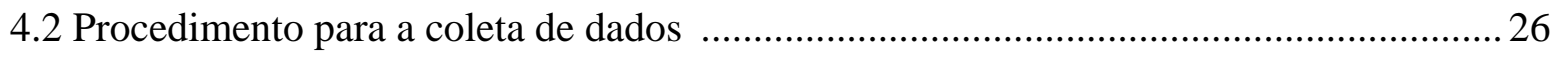

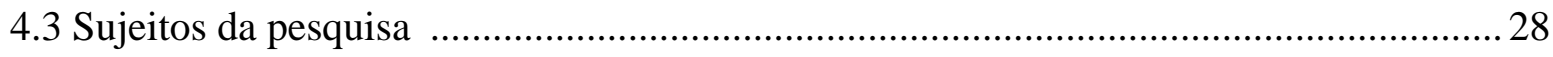

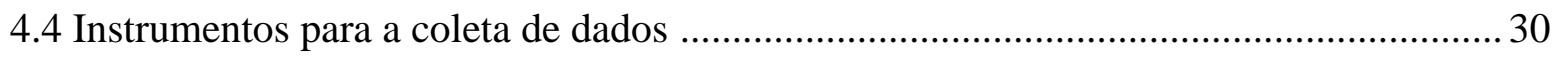

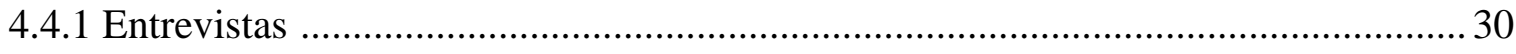

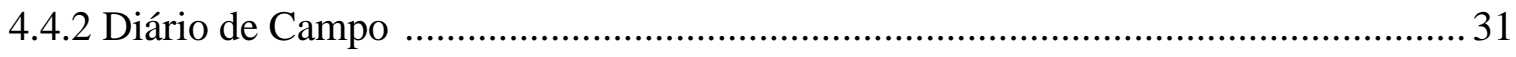

4.5 Análises dos dados e obtenção dos resultados ........................................................... 31

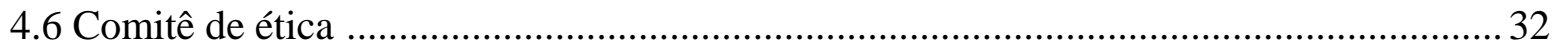

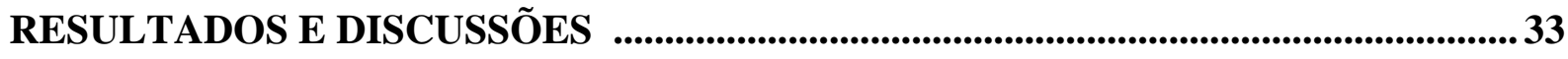

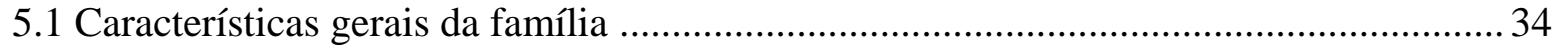

5.1.1 Dados Sócios - econômicos ………….................................................................... 34

5.1.2 As famílias do ponto de vista estrutural ................................................................... 34

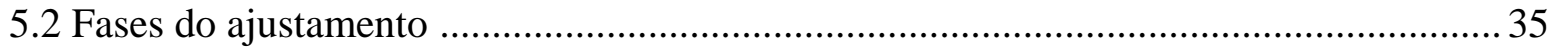

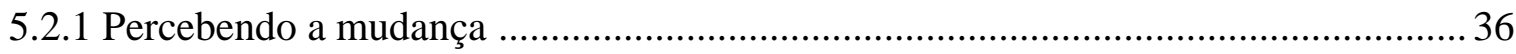

5.2.2 Diagnóstico e início do tratamento .......................................................................... 45

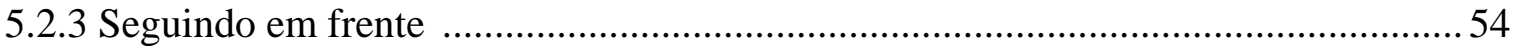

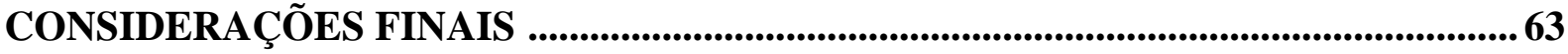

REFERÊNCIAS BIBLIOGRÁFICAS ......................................................................66

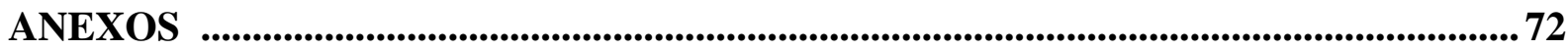

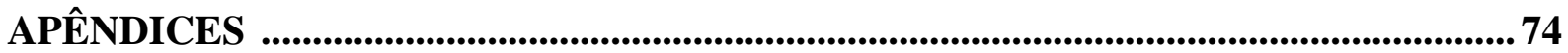


INTRODUÇÃO E REVISÃO DE LITERATURA 


\subsection{Introdução}

A esquizofrenia é um dos principais problemas de saúde pública da atualidade, exigindo considerável investimento do sistema de saúde e causando grande sofrimento para o doente e sua família.

A prevalência do transtorno tem originado uma estimativa aproximada de $0,5 \%$ a $1 \%$. Já a incidência apresenta, aproximadamente, a ocorrência de quatro casos novos em 10.000 habitantes por ano. Apesar da baixa incidência, por ser uma doença de longa duração ou alta prevalência, acumula-se ao longo dos anos um número considerável de pessoas portadoras deste transtorno, com risco muito grande de cronificação (MARI; LEITÃO, 2000).

As causas da esquizofrenia ainda não estão bem estabelecidas, sabe-se que há uma predisposição genética que pode ser desencadeada pela interação de fatores biopsicossociais. Desta maneira, indivíduos com uma predisposição podem desenvolver a doença quando estimulados por estes fatores. O esquizofrênico apresenta uma ampla sintomatologia, porém a sua expressão varia de indivíduo para indivíduo (GIACON; GALERA, 2006).

A própria definição fala que é um transtorno de longa duração, com períodos de crise e remissão que causam uma deterioração do funcionamento e danos/perdas nas habilidades para o doente e sua família, como a diminuição da habilidade para cuidar de si mesmo, para trabalhar, para se relacionar individual e socialmente e para manter pensamentos completos (TOSTES; MORAES, 1989).

A esquizofrenia é um transtorno do pensamento e apresenta como característica principal, sintomas que se caracterizam como disfunções cognitivas e emocionais, acometendo o pensamento inferencial, a linguagem e a comunicação, o monitoramento comportamental, o afeto, a fluência e produtividade do pensamento e do discurso, a capacidade hedônica, a volição, o impulso e a atenção. Estes sintomas são divididos em sintomas negativos e positivos (AMERICAN PSYCHIATRIC ASSOCIATION, 1994; ORGANIZAÇÃO MUNDIAL DA SAÚDE, 1993).

Os sintomas positivos se caracterizam por uma exacerbação ou distorção das funções normais, enquanto os negativos caracterizam-se pela diminuição ou perda de funções normais. Os sintomas positivos são os delírios, alucinações, discurso e comportamentos desorganizados. Os sintomas negativos incluem afeto embotado, alogia e avolição. O diagnóstico de esquizofrenia é dado a partir da junção de sinais e sintomas associados ao 
prejuízo no funcionamento ocupacional ou social (AMERICAN PSYCHIATRIC ASSOCIATION, 1994; ORGANIZAÇÃO MUNDIAL DA SAÚDE, 1993).

A idade de início varia entre 15 a 35 anos. Após o primeiro surto psicótico, o doente experimenta períodos de crises e remissão, progredindo para uma deterioração do funcionamento do indivíduo e da família. Apenas 5\% dos pacientes apresentam um único surto durante toda vida, a maioria apresenta vários surtos, grande parte no início da doença (GIACON; GALERA, 2006). A literatura apresenta evidências de que os períodos de crise, conhecidos como recaída psicótica, estão relacionados com a adesão do paciente ao tratamento psicofarmacológico e psicossocial, com as condições sociais e familiares do paciente (HARPHAM, 2002; KANE; LIEBERMAN, 1987; MEIJEL et al., 2002).

Quando ocorre o primeiro episódio da esquizofrenia a família vive uma situação de estresse que desorganiza todo o grupo. A vida familiar é interrompida e a trajetória de vida pode ser modificada (TESCHINSKY, 2000). A partir daí, a família segue o curso do tempo procurando ajustar-se à nova situação, aprendendo com a convivência, através da tentativa e do erro (GALERA, 2002).

Quando é estabelecido o diagnóstico a vida familiar sofre um impacto, comparado ao trauma vivido por vítimas de catastofres (CONN, 2001; SAUNDERS, 1997). Ocorre uma mudança no cotidiano de cada um dos membros que convivem com o doente. Os membros e as pessoas envolvidas experimentam, inicialmente, variados sentimentos, positivos e negativos em relação ao doente e sua doença, em relação aos conflitos familiares, aos problemas financeiros, discórdia entre o casal, isolamento social e falta de suporte (SMITH, 2004; TESCHINSKY, 2000).

As famílias na atualidade estão sob grande pressão, mais do que há alguns anos atrás. É de se supor, portanto, que famílias que têm entre seus membros um portador de esquizofrenia, estão vulneráveis às pressões da atualidade (BOSS, 1988).

O manejo do estresse pela família é um dos seus grandes desafios na atualidade. Algumas famílias podem ficar estáveis, recolhidas, como em um processo terapêutico, recuperando-se e se fortalecendo. Porém, outras acabam não conseguindo esta paralisação e vivem sob o estresse gerado pela doença (BOSS, 1988).

Após o impacto inicial, a família inicia um processo de ajustamento visando manter certo equilíbrio que propicie vantagens para a sobrevivência de todo o grupo. Acredita-se que se o processo de adaptação não for adequado ou saudável ele poderá contribuir negativamente com a evolução da doença, contribuindo pouco para a estabilização e melhora do paciente, 
resultando em modelos de relacionamento que pode levar todo o grupo para o sofrimento mental (SCHNEIDER, 2000).

Poucas pesquisas têm se dedicado a estudar o processo de ajustamento familiar após o início da doença. A finalidade deste trabalho foi identificar o processo de ajustamento familiar após o surgimento da esquizofrenia.

\section{$1.2 \mathrm{O}$ ajustamento familiar frente à doença mental}

Toda a família apresenta ciclos de desenvolvimento. Cada ciclo envolve tarefas, comportamentos e sentimentos com a finalidade de manter íntegro o grupo familiar. Os estudos sobre os ciclos da vida familiar foram realizados principalmente em língua inglesa, e descrevem os ciclos presentes em famílias Norte Americanas de classe média. A mudança de uma fase para a outra envolve muitas vezes um estado de crise cuja resolução depende de fatores biopsicossociais. O surgimento de uma doença crônica pode influenciar profundamente estes ciclos, criando novas demandas para a família (WRIGHT; LEAHEY, 2002).

O estresse familiar é definido como uma pressão ou tensão no sistema familiar, que geram distúrbios os quais resultam em mudanças para melhor se adequar ao novo. O estresse é um estado necessário para que o sistema familiar se reorganize para enfrentar as demandas dos ciclos de vida dos seus membros e do ciclo de todo o grupo. A mudança que ocorre na família é resultado do grau de estresse que a família vivencia, e da percepção que a família tem do evento (BOSS, 1988).

Quando um membro da família é diagnosticado com esquizofrenia, ocorre uma tensão no sistema familiar. A vida familiar é transformada e sua trajetória é modificada, podendo ser acompanhada por varias experiência de perda (JUNGBAUER et al., 2004). Nesta perspectiva, a família altera seu modo de funcionamento para se ajustar a essa nova pessoa doente. Ela se organiza e se reorganiza continuamente, na tentativa de cuidar da maneira mais idealizada de seu membro doente. Muitas vezes, esta tentativa se torna a causa de todo sofrimento familiar e a inadequação do manuseio de sentimentos e do cuidado do paciente (CHESLA, 2005; OLIVEIRA; LOYOLA, 2004).

Assim, cada membro da família acaba por assumir responsabilidades e papéis para facilitar a convivência e o cuidado do membro doente, na tentativa da manutenção do 
equilíbrio da vida familiar antes do surgimento da doença. Essa responsabilidade ou papel assumido por um membro da família em função do outro acaba por gerar outra sobrecarga, podendo causar mais um fator de desequilíbrio dentro do grupo familiar. Estudos mostram que os membros femininos da família, com um membro doente dentro da mesma casa, passam por uma sobrecarga mais intensa que os membros masculinos, sofrendo principal influência da cultura na qual estão inseridos (JUNGBAUER et al., 2004; OLIVEIRA; LOYOLA, 2004)

No caso da esquizofrenia, em sua maioria, os pais assumem o papel do principal cuidador, se tornando o mais importante e permanente contato social destes doentes. Forma-se então um relacionamento indissolúvel e longo, principalmente entre os pais e o doente, enquanto que para os cônjuges estabelece-se um relacionamento solidário, que pode ser rompido em períodos de extrema sobrecarga. Esta mudança no ciclo familiar gerada pela convivência com a esquizofrenia acarreta o desenvolvimento de problemas intensos para ambos, pais e doente e, em sua maioria, em menos intensidade para os demais membros da família (JUNGBAUER et al., 2004).

Considerando que existe o elemento tempo cronológico e cultural determinando momentos de mudança na vida das famílias é de se supor que as relações familiares descritas acima ocorrem através de um processo de arranjos e desarranjos ao longo do tempo. Um processo de ajustamento.

Com o objetivo de identificar as fases de enfrentamento de famílias com problemas de saúde mental, Muhlbauer (2002) desenvolveu pesquisa qualitativa fundamentada no interacionismo simbólico, utilizando a técnica da dramaturgia para a coleta de dados. Foram entrevistados 26 familiares explorando as experiências dos participantes frente à doença mental. Os dados foram analisados no desenvolvimento de uma seqüência de fases que a família vivencia. Essas fases são: desenvolvimento da consciência, crise, ciclo de instabilidade e diminuição da crise, movimentação para retorno da estabilidade, continuação da estabilidade, crescimento e defesa.

Outro estudo com objetivo de conhecer as fases de adaptação familiar foi realizado por Johannes Jungbauer et al. (2002). Neste estudo foram entrevistados 51 pais de paciente com esquizofrenia, os quais foram questionados a respeito de seu presente convívio com a doença, as mudanças, o ciclo familiar e a sobrecarga. Estas informações foram coletadas em três momentos diferentes, com intervalo de seis meses entre uma entrevista e outra. A técnica de narrativa foi utilizada para conduzir as entrevistas. Foram encontrados seis diferentes tipos de desenvolvimento da sobrecarga: constante elevação do nível de carga devido à função 
psicossocial prejudicada, sendo esta notificada em pais de pacientes com severa e permanente função psicossocial prejudicada, relatando principalmente elevado consumo de tempo e necessidades diárias de cuidados; carga elevada devido à deterioração causada pelos sintomas da doença; redução contínua da carga após a recaída ou episódio recente; substituição da carga; predominância de outras cargas; e constante redução do nível de carga.

Em 2004, Jungbauer et al., realizaram uma pesquisa qualitativa, com coleta de dados a partir de entrevistas e da narração, tendo como principal objetivo a exploração de problemas de desenvolvimento e do "detachment”. "Detachment” é o desenvolvimento de tarefas que devem ser manejadas por ambos, pais e filhos, e que podem vir acompanhadas por demandas e problemas específicos. Participaram do estudo 51 pais de paciente com esquizofrenia, com tempo médio de diagnóstico de 11 anos e uma média de idade de 33 anos. Eles encontraram como principais resultados à permanência dos filhos no convívio dos pais, devido à intensa dependência deste na realização de tarefas de auto-cuidado; o retorno do filho independente ao círculo familiar primário após o adoecimento; dificuldade moral e social de transferir o cuidado para instituições de saúde; a emoção envolvida no cuidado e a restrição das relações apenas em âmbito familiar; a sobrecarga financeira pela perda de uma mão de obra que geraria uma renda financeira e devido o não conhecimento dos direitos legais deste membro doente, apoiando-se muitas vezes em contribuições voluntárias ou reservas financeiras; incerteza sobre quem cuidará do seu filho; o paradoxo do que é melhor, o alto nível de suporte dado pela família, ou centros de cuidados especializados que possam desenvolver neles algum grau de independência; e o não cumprimento do plano de vida sonhada para o filho e a diferença entre ele e outros membros da família.

Como conclusão, estes estudiosos percebem que muitos conflitos são desenvolvidos dentro da família e que os pais acabam assumindo grande parte do cuidado do membro doente e do “detachment”, o que acaba gerando separação familiar, na maioria das vezes. Outra conclusão importante é que os pais acabam julgando as relações restritas positivas, pois passa a ser compatíveis com os novos planos desenvolvidos para este circulo familiar.

Chesla (2005) relata que famílias com pessoas com doenças crônicas vivenciam relações dialéticas, caracterizando-as como “paradoxo existencial da doença crônica”. Ela nomeia a vivencia destas famílias como paradoxo, pois ao mesmo tempo em que esta família, junto com o membro doente, experimenta limitações e perdas, eles aprendem sobre possibilidades, esperanças, isto é, novas aberturas, mudanças positivas e criativas para possibilidade de vida no presente. A família muda suas prioridades em interesse, em resposta 
à nova situação atual, com maior facilidade quando existe um elo forte de sentimento positivo com o membro doente.

A autora relata que a família vivencia constantemente momentos de sofrimento, como a preocupação e incerteza com o futuro, quando o doente sai sozinho e demora pra voltar pra casa, dificuldades enfrentadas em âmbito social e financeiro, entre outros. Desta maneira, ela acredita que estes momentos de sofrimento levam a família ao insight, tendo como conseqüência novas mudanças positivas, as quais vão construindo dinamicamente uma adaptação adequada, a todas as pessoas envolvidas.

Não encontramos na literatura de enfermagem e de saúde mental brasileira estudos voltados para a adaptação familiar frente à esquizofrenia ou outro transtorno mental grave e crônico. Os estudos de língua inglesa analisados até o momento descrevem o processo de adaptação familiar a partir da perspectiva de familiares de doentes mentais que estão em diferentes fases da vida. Geralmente a idade do doente é de 40 anos e o tempo de doença varia de 10 a 15 anos. Portanto com famílias em diferentes estágios do desenvolvimento tanto em relação ao ciclo de vida familiar quanto à evolução da doença.

Embora trabalhem com um número expressivo de participantes (26 a 51), estas pesquisas não permitem verificar se determinados comportamentos ou modelos de interação da família ocorrem desde o inicio da doença ou em qual momento eles ocorrem. Neste sentido, este trabalho propõe-se a focalizar o processo de adaptação em famílias que estão convivendo com o adoecimento mental nos primeiros cinco anos após o diagnóstico de esquizofrenia. 


\section{OBJETIVO}


O objetivo deste trabalho foi identificar e analisar o processo de ajustamento familiar nos primeiros cinco anos após o diagnóstico de esquizofrenia. 


\subsection{Referencial Teórico Metodológico}

Esta pesquisa apoiou-se em conceitos do interacionismo simbólico, do referencial sistêmico de família e de trajetória de vida. Na perspectiva do interacionismo simbólico os indivíduos atribuem significados às suas ações, e a partir destes, estruturam o seu relacionamento com as pessoas e com o ambiente no qual está inserido, construindo, de um modo dinâmico, suas vidas.

O interacionismo simbólico dá ênfase no significado que o individuo estabelece a determinada situação a qual ele está vivenciando. Este significado simbólico é construído através das experiências do indivíduo ou do seu grupo, por exemplo, a família, através da interação com o meio físico e social no qual estão inseridos e da importância que determinado fato constitui. Sua perspectiva teórica focaliza a conexão entre os símbolos (e significados) e a interação social do indivíduo ou grupo, através da maneira como definem os eventos ou a realidade e como agem em relação as suas crenças. Dessa maneira, toda e qualquer vivência interfere e altera o funcionamento da família, que busca sempre uma forma de reestruturação e rearranjo, para continuar visando seus ideais, sejam eles novos ou antigos. Assim, a família possui capacidade de adaptabilidade para manter e perpetuar o seu contínuo movimento de almejar o bem viver (SAUNDERS, 1977; WRIGHT; LEAHEY, 2002; YAMASHITA, 1998).

Esse referencial é selecionado como um guia estrutural desta pesquisa, pois define família como um grupo social que desenvolve conceitos e identidade própria através da interação entre si e com os indivíduos que se relacionam, dentro do âmbito social em que vive. A família atribui significados a essas experiências, as quais resultam de suas interações. Dessa maneira, esse referencial pode ajudar a enfermagem a trabalhar mais efetivamente com familiares de doentes mentais, pois ele avalia o significado imposto, a partir de seus membros, em âmbito familiar e individual (HEATH; COWLEY, 2004; NICO et al., 2007; PETTENGILL; ANGELO, 2005; SAUNDERS, 1977)

A perspectiva sistêmica e a interacionista de família se articulam no ponto em que ambas reconhecem que toda e qualquer experiência interfere e altera o funcionamento da família, que busca sempre uma forma de reestruturação e rearranjo, para continuar visando seus ideais, sejam eles novos e/ ou antigos. Assim, “a família possui capacidade de adaptabilidade para manter e perpetuar o seu contínuo movimento de almejar o bem viver" (WERNET; ANGELO, 2003). 
O conceito de família é construído em um processo dinâmico de conhecimentos. Sua construção sofre influência de aspectos políticos, econômicos, sociais e culturais da sociedade, não esquecendo também, do propósito para o qual ele está sendo formado. Assim como o conceito de saúde, o conceito de família inicialmente foi construído focado nos relacionamentos interpessoais, valorizando o indivíduo como unidade de um grupo (ROBINSON, 1995; STUART, 1991).

Atualmente, muitos estudiosos têm adotado família como unidade, isto é, não como a soma de relacionamentos interpessoais, mas como uma estrutura relacional na qual esses relacionamentos estão inseridos. Desta maneira pode-se entender a família e suas singularidades, assim como os membros que a formam e suas individualidades. Essa dicotomia existente só realça a necessidade de criar estratégias diferentes para a família e para os seus membros, tanto na pesquisa como na prática de enfermagem (ROBINSON, 1995; VAUGHAN-COLE, 1997).

Para estabelecer quem são os sujeitos da pesquisa é necessário estabelecer uma definição do termo família. A definição adotada neste projeto de pesquisa é aquela apresentada por Wright e Leahey, e se inspira na Teoria Geral de Sistemas, na Teoria da Cibernética, na Teoria do Conhecimento elaborada pelo biólogo Humberto Maturana e seus colaboradores, em Conceitos de Enfermagem e da Terapia Familiar Sistêmica, principalmente nos trabalhos da "equipe de Milão"( GALERA; LUIS, 2002; WRIGHT; LEAHEY, 2002).

Do ponto de vista sistêmico, a família é definida como sendo "um grupo de indivíduos (elementos) ligados por fortes vínculos emocionais, com o sentido de posse e a inclinação a participar das vidas um dos outros”. O sistema familiar é composto por muitos subsistemas, como pais-filho, cônjuge e irmão, e está aninhado em um supra-sistema mais amplo, constituído pelos diversos setores da sociedade. Uma mudança em qualquer parte do subsistema, sistema e supra-sistema inevitavelmente trará uma mudança em outras partes (WRIGHT; LEAHEY, 2002).

Na perspectiva deste referencial, a família pode ser comparada a um móbile, que quando tocado, movimenta toda sua estrutura e vai se equilibrando novamente. Conseqüentemente, uma mudança em uma parte do sistema inevitavelmente trará uma mudança em outras partes (GALERA; LUIS, 2002). Nesta perspectiva, quando um membro da família adoece, todos os membros também são afetados. Isto ocorre devido aos mecanismos reguladores dos sistemas e aos processos de retroalimentação.

Desta maneira, os autores defendem que os problemas de saúde e a dinâmica familiar são mais bem compreendidos a partir da perspectiva da causalidade circular. Os comportamentos dos membros da família geram um efeito que influencia o membro doente e, por outro lado, os 
comportamentos do doente influenciam a dinâmica familiar. Estes estudos demonstram que tanto sentimentos positivos como negativos, atitudes, compreensão e aceitação da doença, hostilidade, entre outras reações expressadas, influenciam direta e indiretamente o prognóstico da doença e o ajustamento saudável ou não da família e do membro doente. Isto gera uma resposta positiva ou negativa de um dos lados, formando um circulo de ação e reação, dinâmico e contínuo (GALERA; LUIS, 2002; WRIGHT; LEAHEY, 2002).

A perspectiva de que a vida é construída baseada em uma trajetória de experiências, conhecimentos e mudanças, em que o indivíduo transita, desde o seu nascimento até a sua velhice. Neste trabalho, esta perspectiva foi usada para estudar o processo de ajustamento das famílias no inicio da doença mental.

A trajetória de vida é assumida como uma orientação teórica para estudar relações sociais, indivíduos e família. Na literatura encontramos sua definição como sendo a seqüência de eventos que ocorrem na vida de um indivíduo ou de um grupo, dentro de um contexto sociocultural e histórico, a partir dos caminhos sociais em que estão envolvidos, da dinâmica de suas relações e dos elementos internos e externos que agem, direta e indiretamente, sobre eles. Assume-se como caminhos sociais aqueles que focalizam a seqüência de um papel na formação da trajetória de vida. As crianças amadurecem, casam-se e tem filhos os quais recomeçam este ciclo, continuando de geração a geração (ELDER JUNIOR; JOHNSON; CROSNOE, 2003).

Desta forma, esta definição é construída associada a outros termos, como: períodos de vida, história de vida e ciclos de vida. Período de vida refere-se a uma porção da vida, por exemplo, infância, adolescência, etc. História de vida é o conjunto de ações e eventos durante a trajetória de vida. Ciclo de vida é um termo usado para descrever a seqüência de eventos na vida (ELDER JUNIOR; JOHNSON; CROSNOE, 2003).

Seguindo a idéia da trajetória de vida, a família tem como expectativa construí-la dentro do contexto sociocultural e histórico no qual está inserida. Neste contexto, os membros da família têm que administrar, em conjunto, períodos de transição, como: quando um filho entra na escola, quando um pai muda de trabalho, quando uma pessoa mais velha da família morre. A administração destes períodos se baseia no ajustamento do grupo frente às mudanças, por meio da trocas de papéis esperados, como um adolescente se tornar adulto, assumindo as respectivas responsabilidades desta fase (WRIGHT; LEAHEY, 2002; JUNGBAUER et al., 2004; DUHAMEL; TALBOT, 2004).

Uma família que possui um filho adolescente se organiza para se ajustar a um novo evento previsível, que é a transição da adolescência para a vida adulta. Este período se 
caracteriza por mudanças biológicas, emocionais e socioculturais rápidas. Há o estabelecimento de um novo tipo de relacionamento com seu filho, que é a mudança de um relacionamento de dependência estabelecido com a criança para a um cada vez mais independente com o adolescente, que começa a criar sua nova identidade (WRIGHT; LEAHEY, 2002; CERVENY; BERTHOUD, 2002).

Este período de transição é bem descrito em estudos sobre a classe média americana (WRIGHT; LEAHEY, 2002) e brasileira (CERVENY; BERTHOUD, 2002). Os pais passam de protetores a preparadores, ajudando seu filho na maturação de questões sociais e sexuais, como: formulação de valores, estilos de vida, planos de carreira e relacionamentos pessoais. Em um estágio mais avançado, quando passam a ser reconhecidos como jovens adultos, os filhos estabelecem uma relação mais igualitária com os pais, baseada no respeito mútuo e na troca de experiências. Este inicia o planejamento e execução da sua vida independente, financeira e socialmente, mas sem que os laços familiares sejam rompidos (WRIGHT; LEAHEY, 2002; CERVENY; BERTHOUD, 2002).

Ela também sofre influencia de eventos imprevisíveis para o indivíduo ou para a família. Por exemplo, uma gravidez na adolescência de um dos filhos, a reprovação de um filho na escola, o desemprego, o adoecimento e/ou a morte de um membro, enfim, eventos que ocorrem sem ser esperados ou fora do período de vida esperado. Considerando que a esquizofrenia tende a aparecer na transição da adolescência para a vida adulta ou no início da vida adulta, é provável que ocorra uma transformação na construção da trajetória de vida da família que está vivenciando o adoecimento de um de seus jovens (PEJLERT, 2001; STEIN; WEMMERUS, 2001).

Quando um jovem é diagnosticado com esquizofrenia, ele e sua família experimentam este evento como uma força destrutiva que transforma a trajetória de vida da família. Eles vivenciam sentimentos de insegurança, perda de atividades e sonhos que estão em andamento ou viriam a ser realizadas, assim como modificações em seu relacionamento familiar. A trajetória de vida da família é dividida em duas etapas, antes e após o adoecimento de um membro (CHESLA, 2005; PEJLERT, 2001).

Estes eventos podem causar uma interrupção na trajetória de vida, obrigando com que, este indivíduo ou a família se ajuste a nova realidade que estão vivenciando. Este ajustamento pode ocorrer de forma saudável ou não, o que depende da maneira de como o fato é absorvido pela família, como ocorre seu reconhecimento e como esta se organiza para vivenciá-lo (HARDEN, 2005; STEIN; WEMMERUS, 2001). 


\subsection{Método}

Seguindo essa linha teórica, estabelecemos neste estudo o uso da Teoria fundamentada nos dados, como método de pesquisa e de análise dos dados. Este método está inserido dentro da pesquisa interpretativa e localizado como uma variante dentro do interacionismo simbólico. A teoria fundamentada nos dados é um método de pesquisa de campo com o objetivo de gerar construtos teóricos indutiva e dedutivamente, assentada nos dados, que explicam a realidade observada a partir das ações dos indivíduos. Tem como objetivo investigar processos sociais básicos que estão acontecendo na cena social, partindo de hipóteses que quando relacionadas podem explicar o fenômeno, entender a multiplicidade destas interações e sua interferência e variação nestes processos. Deixa-se claro que este método constrói uma teoria que tem como objetivo acrescentar novas perspectivas ao fenômeno, isto é, identificar, desenvolver e relacionar conceitos (CASSIANI; CALIRI; PELÁ, 1996; HEATH; COWLEY, 2004; NICO et al., 2007; SAUNDERS, 1977).

Este método é formado por três tipos de elementos: primeiramente as categorias e suas propriedades conceituais as quais são formadas a partir dos dados coletados; em segundo, as hipóteses ou relações geradas entre as categorias e suas propriedades, sendo estas provisórias; e por último, a delimitação da teoria, como fase final. Para a análise dos dados optamos por utilizar as etapas estabelecidas por Glaser e Strauss (1967): coleta dos dados empíricos; os procedimentos de codificação ou análise dos dados (codificação aberta, codificação axial ou formação e desenvolvimento do conceito, codificação seletiva ou modificação e integração do conceito); e delimitação da teoria (CASSIANI; CALIRI; PELÁ, 1996; HEATH; COWLEY, 2004; NICO et al., 2007; SAUNDERS, 1977).

\subsection{Procedimento para a coleta de dados}

A coleta de dados foi conduzida através de uma entrevista (APÊNDICE A) realizada com familiares de portadores de esquizofrenia. Os participantes foram contatados por meio da lista de pacientes atendidos no Núcleo de Saúde Mental do Centro de Saúde Escola (CSE) e no Ambulatório de Esquizofrenia Precoce do Hospital das Clínicas de Ribeirão Preto (HCRP), ambos os serviços da Faculdade de Medicina de Ribeirão Preto (FMRP) da Universidade de 
São Paulo (USP). Tanto o familiar como o paciente foram esclarecidos quanto ao objetivo do estudo e assinaram o Termo de Consentimento Livre e Esclarecido (APÊNDICES C e D). As entrevistas foram realizadas no serviço onde cada portador de esquizofrenia realiza seu tratamento e foram gravadas em fita cassete.

Quando o projeto foi elaborado, tinha-se estabelecido três encontros com cada família. O primeiro encontro teria a finalidade de iniciar o estabelecimento do vínculo com a família participante, confeccionar o genograma e realizar a entrevista semi-estruturada (APÊNDICE A). Após este encontro, a entrevista seria transcrita e seria realizada uma análise prévia com o objetivo de identificar pontos chaves a serem trabalhados, de acordo com os objetivos propostos. A segunda entrevista teria a função de explanar os pontos relevantes encontrados na análise previa e de validar o genograma. Da mesma maneira, esta segunda entrevista seria transcrita pelo pesquisador e sua análise seria feita para caracterizar o processo de ajustamento exposto pela família. Na terceira entrevista, este processo seria validado pelo grupo. Por fim, após todos os dados colhidos e validados, seria iniciado o processo de análise baseado no método da Teoria fundamentada nos dados com o objetivo de identificação do processo de ajustamento familiar no período estipulado. Contudo, a coleta de dados se deu de maneira diferente da estabelecida inicialmente, devido às dificuldades encontradas que serão descritas a seguir.

De inicio, foram levantados os pacientes portadores de esquizofrenia de cada serviço. Este processo se deu através das agendas de retornos médicos e levantamento de prontuários. Foram encontradas um total de 32 famílias que atendiam os critérios da pesquisa, sendo que 14 famílias no Núcleo de Saúde Mental - CSE - FMRP - USP e 18 famílias no Ambulatório de Esquizofrenia Precoce do HCRP - FMRP - USP. Com as famílias selecionadas, foi realizado um primeiro contato por telefone, com pelo menos um mês de antecedência do retorno ao serviço, e quando não tinham telefone, pessoalmente na sala de espera do serviço.

Neste primeiro contato identificava-me e explicava sucintamente os objetivos da pesquisa. Assim, convidava a família, isto é, os familiares interessados e disponíveis, a participar de uma entrevista que seria realizada no próprio serviço de saúde em que o membro fazia acompanhamento, minutos antes ou depois da consulta (de preferência e disponibilidade de cada família). Uma semana antes de cada retorno, um novo contato via telefone era feito com cada família, para confirmação do encontro ou agendamento de outra data.

Porém, muitas das famílias entrevistadas faltavam do retorno agendado, re-agendavam a consulta médica sem aviso prévio da pesquisadora ou chegavam sem disponibilidade de 
tempo para as entrevistas. Das entrevistas realizadas, um terço foi re-agendadas para datas posteriores.

Quando uma família, contatada por telefone, recusava-se a participar, esta era procurada no dia do retorno médico. Uma nova apresentação da pesquisa e um novo convite de participação eram feitos. Deixou-se a critério das famílias a escolha da participação e uma nova data para o encontro. Das 32 famílias contatadas, apenas 21 famílias aceitaram participar da pesquisa.

Os encontros foram restritos a apenas um porque todos os familiares participantes referiram pouca disponibilidade de tempo. Geralmente esses participantes eram os únicos responsáveis pelo cuidado diário do doente, além de outras responsabilidades domésticas. Assim as tarefas daquele dia deviam ser cumpridas por aquele cuidador e, por mais que, as entrevistas fossem agendadas previamente, imprevistos e compromissos surgiam, o que fazia com que a participação dos familiares fosse deixada para outro dia. Portanto, para que um número maior de famílias participasse da pesquisa, foi realizada apenas uma entrevista com cada família.

Cada encontro se organizou de maneira espontânea de acordo com o discurso de cada entrevistado, contemplado a construção do genograma, aplicação do questionário sóciodemográfico (APÊNDICE B) e a realização da entrevista estabelecida (APÊNDICE A).

\subsection{Sujeitos da pesquisa}

Quando se trabalha com famílias, deve-se atentar para a escolha da amostra que fornecerá os dados para obtenção dos resultados. Muitas pesquisas realizam a coleta de dados a partir do ponto de vista de um familiar. Um viés existente nesta amostra é que alguns familiares podem ter a dificuldade de relatar aspectos da vida familiar, de relacionamentos existentes, questões como abuso de substancias, violência doméstica ou vida sexual, entre outros. Com isso, pode ocorrer a perda de vários dados da família que não é relatado pelo familiar participante. Para solucionar este problema pesquisadores defendem que a coleta de dados, para este tipo de pesquisa, deve ser realizada com dois ou mais familiares de cada família participante e que deve se estabelecer critérios para eleger os participantes (MORIARTY, 1990; VAUGHAN-COLE, 1997). 
Assim, foram seguidos os critérios de inclusão e exclusão, previamente estabelecidos, para seleção dos participantes da pesquisa. O informante deveria ter idade superior a 18 anos, não ter diagnóstico de doença mental, ter contato com o paciente diariamente (apenas um entrevistado não tinha contato diariamente com o doente, mas sim freqüentemente), mesmo que não morasse na mesma casa. Quando o paciente fosse casado ou vivesse com algum companheiro este seria incluído na pesquisa. Porém, na nossa amostra, apenas um dos pacientes possuía companheiro. Crianças não foram entrevistadas. Familiares que participam da vida do doente esporadicamente não foram considerados bons informantes.

Os familiares particiantes selecionados a partir da realização de um levantamento dos pacientes que cumpriam os critérios de inclusão relacionados ao adoecimento. Assim, entrouse em contato com familiares de 32 pacientes, que foram diagnosticados como esquizofrênicos quando tinham idade entre 15 e 25 anos. O período entre o diagnóstico e a nossa entrevista não ultrapassou cinco anos.

Após o convite para participação, esbarrou-se na de disponibilidade dos entrevistados. Em todas as famílias, apenas um familiar ficava responsável pelo cuidado do doente no dia, enquanto os demais se envolviam em outras tarefas para funcionamento e organização da família. Então, como as entrevistas foram realizadas nos serviços de saúde de acompanhamento do doente, houve apenas o comparecimento de um familiar. Mesmo com o convite prévio, o familiar presente alegava que os demais estavam ocupados com outras atividades e por isso não puderam comparecer. Somente em dois casos participaram dois familiares, o pai e a mãe e duas irmãs. Assim, participaram da pesquisa 23 familiares de 21 famílias que aceitaram participar do estudo proposto. A condução da entrevista foi apoiada no referencial sistêmico, que permite elaborar questões para uma pessoa representante da família, mas solicitando que ela focalize suas respostas não apenas nela, mas em todos os membros do grupo familiar.

Julgando que a presença do doente na entrevista poderia inibir os familiares, pedíamos quando possível que o doente não participasse da pesquisa, mas autorizasse a participação de seus familiares. Das 21 entrevistas, cinco contaram com a participação do doente. Este fato ocorreu porque as entrevistas foram realizadas no serviço de saúde de acompanhamento do doente e, em sua maioria, nos dias de retorno. Como os acompanhantes tinham medo de deixar o familiar doente sozinho na sala de espera por aproximadamente 40 minutos, foi autorizado à permanência deles na sala durante o período da entrevista.

Estes familiares julgaram indiferente a presença do membro na entrevista. Pediu-se ao doente a participação apenas como ouvinte, interferindo o mínimo possível. Por ter conduzido 
as entrevistas, acredito que não houve interferência nos dados, pois os familiares participantes não se mostraram incomodados em contar a historia do adoecimento na frente do doente.

\subsection{Instrumentos para a coleta de dados}

Foi utilizada uma entrevista familiar contendo a construção do genograma, uma questão aberta (APÊNDICE A), um formulário sócio demográfico (APÊNDICE B) e o diário de campo.

\subsubsection{Entrevistas}

A entrevista (APÊNDICE A) teve por objetivo traçar a história do ajustamento familiar, do ponto de vista dos familiares entrevistados. Foi pedido para que os familiares descrevessem como foi o processo de ajustamento para a família após o inicio do adoecimento de um de seus membros.

Para auxiliar o desenvolvimento da pesquisa, foi construído o genograma familiar. O genograma é um diagrama da constelação familiar, utilizado para conhecer a estrutura interna da família e como esta se relaciona dentro do seu sistema e no supra-sistema no qual está inserida. A utilização deste instrumento é simples porque ele necessita como material, somente papel e caneta. O genograma utiliza-se de símbolos que são universalmente adotados pela genética e genealogia para facilitar a comunicação profissional.

Optou, neste trabalho, pelo uso da entrevista aberta, semi-estruturada, solicitando que os participantes falassem sobre o processo de ajustamento da família frente ao surgimento da esquizofrenia. Isto é, para que eles relatassem o fenômeno partindo do passado, com o início do adoecimento, o presente e quais as expectativas e sentimentos esperados para o futuro.

Neste tipo de entrevista, o pesquisador simplesmente solicita aos participantes que falem da história da família e sobre suas experiências com respeito ao tema e os critérios da pesquisa. O pesquisador pode usar questões adicionais para manter o foco da entrevista sobre o tema da pesquisa e para obter uma descrição detalhada de experiência que está sendo relatada. (MAYAN, 2001). 


\subsubsection{Diário de Campo}

O diário de campo foi usado para descrever comportamentos verbais e não verbais dos participantes, reflexões, sentimentos, idéias, momentos de confusão, pressentimentos e as interpretações da pesquisadora sobre as observações que pudessem ajudar na análise dos dados obtidos. Uma parte do diário de campo foi usada também para reflexões sobre o método e reflexões para a análise de dados.

\subsection{Análises dos dados e obtenção dos resultados}

As entrevistas foram ouvidas pela pesquisadora e transcritas imediatamente. $\mathrm{O}$ texto resultante foi revisado diversas vezes e toda referência que pudesse identificar o participante ou pessoas citadas por ele foram eliminadas com o objetivo de proteger a identidade do participante, do paciente e de outras pessoas envolvidas no processo. Utilizou-se a análise de dados proposta pela teoria fundamentada nos dados e as etapas estabelecidas por Glaser e Strauss (1967).

Após a obtenção dos textos, o investigador examinou linha por linha e recortou as unidades de análise. As unidades de análise nesta pesquisa refere-se ao processo de ajustamento familiar. Cada unidade de análise foi nomeada com uma palavra ou sentença que refletissem o entendimento do pesquisador sobre o processo de ajustamento familiar. Além disso, cada unidade era identificada através da linha do tempo, isto é quando o texto fazia referencia ao inicio do adoecimento, à infância do doente, ao período do diagnóstico ou ao período atual.

Em seguida as unidades de análise foram agrupadas segundo o momento do adoecimento a que se referiam. Após isso, foi realizada a codificação aberta, que se caracteriza pela comparação dos incidentes aplicáveis a cada categoria. Estes são codificados em tantas categorias possíveis, lembrando que todos os dados nestes momentos podem ser codificados. A codificação é o processo no qual os dados são comparados com outros dados e designados em categorias. (CASSIANI; CALIRI; PELÁ, 1996; HEATH; COWLEY, 2004)

Paralelamente a esta etapa, foram elaborados os memorandos, que pretendiam formular um entendimento sobre as categorias criadas. (ASBRING, 2001; CASSIANI; 
CALIRI; PELÁ, 1996; HEATH; COWLEY, 2004; PEJLERT, 2001; SCANLON, 2006). Os dois passos seguintes, codificação axial e seletiva não foram realizados neste momento, pois exigiriam mais tempo e um maior aprofundamento do pesquisador.

\subsection{Comitê de ética}

O projeto foi encaminhado e aprovado pelo Comitê de Ética em Pesquisa do Hospital das Clínicas da Faculdade de Medicina da Universidade de São Paulo, o qual foi aprovado, de acordo com o processo HCRP n ${ }^{\circ}$ 9800/2007 (ANEXO A). 
RESULTADOS E DISCUSSÕES 


\subsection{Características gerais da família}

\subsubsection{Dados Sócios - econômicos}

As 21 famílias estudadas nesta pesquisa têm uma renda mensal fixa que variou de um a sete salários mínimos, sendo que apenas duas tinham a renda mensal acima de sete salários mínimos. As famílias recrutadas no Núcleo de Saúde Mental do CSE - FMRP possuem renda menor que as que fazem acompanhamento no Ambulatório de Esquizofrenia Precoce do HCRP - FMRP. São constituídas em media por cinco membros, sendo pais e filhos, uma media de dois a três filhos por família. Das 21 famílias, apenas duas moram em casa de aluguel e duas dividem o quintal com outras famílias, sendo que uma divide com a família da irmã.

\subsubsection{As famílias do ponto de vista estrutural}

Das 21 famílias participantes, nove mantiveram a formação estrutural desde o começo do adoecimento até o período atual. Doze famílias passaram por um processo de mudança. Em seis, essas mudanças ocorreram independentemente do adoecimento do familiar e nas outras seis essas mudanças foram conseqüência do adoecimento.

Das seis famílias em que as mudanças não ocorreram devido ao adoecimento do familiar, em duas famílias a mudança ocorreu seguindo o desenvolvimento esperado socialmente. Isto é, um ou mais membros se casaram e formaram seus próprios núcleos familiares, saindo da casa dos pais. Em outra, um dos filhos casou, porém, separou-se do companheiro e retornou ao núcleo familiar inicial. Em uma família, o irmão do doente começou a trabalhar e foi morar na moradia oferecida pelo serviço. Em outra família a mudança no núcleo familiar ocorreu devido ao conflito entre o filho mais velho e o atual companheiro da mãe do doente. E na última, houve o nascimento de duas crianças, sobrinhas do doente, que passaram a conviver na casa onde vivia o doente.

Nas seis famílias nas quais a mudança estrutural ocorreu como conseqüência ao aparecimento da doença identificamos em duas a separação dos pais do doente devido à 
dificuldade de convivência com o adoecimento dos filhos. Em uma dessas duas famílias, observou-se a saída de um filho no inicio do adoecimento, e seu retorno ao núcleo familiar após o inicio do tratamento.

Em outra família, após o adoecimento do filho, o pai que havia saído do convívio da família há aproximadamente 20 anos, retorna a viver com a ex-esposa e o filho doente. Assim, a mãe e o filho doente, que viviam com a avó materna, saem da casa desta e refaz um núcleo familiar, que passa a ser constituído pelos pais e o doente.

Há também outra família em que a mãe, com uma doença pulmonar, se desloca do Maranhão à Ribeirão Preto para a realizar seu tratamento. Alguns anos depois, a filha que havia ficado no Maranhão com o pai e demais irmãos, adoeceu e a mãe a trouxe para Ribeirão Preto para realizar um tratamento adequado para os sintomas que estava apresentando.

Em um grupo familiar, com a confusão entre sintomas relacionados à doença ou ao uso de drogas, a tia materna que era responsável pelo cuidado do doente, devolve-o para o cuidado da mãe. A mãe, com problemas de saúde, mora com a filha casada. Como sua filha estava grávida, não queria a presença de seu irmão doente em casa e assim este foi morar com o pai. E na última dessas seis famílias, ao contrario das demais, há o retorno de um familiar, no caso, a irmã do doente, para o convívio com os pais e o irmão doente, na tentativa de ajudar no tratamento e restaurar o equilíbrio da família.

Em relação à existência de outros casos de doença psiquiátrica na família, sete familiares participantes, das 21 famílias estudadas nesta pesquisa, referiram lembrar-se de casos de doença na família. Esses casos foram referidos a gerações anteriores ao do doente, como avos, pais, tios e primos. Alguns conseguiam saber o diagnostico, porém a maioria referiu apenas que haviam um ou mais familiares que "tinham problemas de nervos", "faziam tratamento para a cabeça” ou “já foram internado em um hospital psiquiátrico”.

\subsection{Fases do ajustamento}

Como descrito anteriormente, a coleta de dados foi conduzida baseada em uma entrevista (APÊNDICE A) que teve como objetivo traçar a história do ajustamento familiar, do ponto de vista dos familiares entrevistados. Foi pedido para que os familiares participantes descrevessem como foi o processo de adoecimento do seu membro e de ajustamento da família a esse processo. Ao iniciarem seus relatos todos os entrevistados se referiram a um 
período anterior ao adoecimento, aquele em que eles perceberam o início da mudança de comportamento do familiar. Assim, a primeira fase identificada nesta pesquisa refere-se ao período anterior ao diagnóstico e foi nomeada "Percebendo a Mudança”.

Um aspecto interessante no relato dos entrevistados é que eles fizeram comentários sobre o comportamento do familiar doente antes dos problemas acontecerem. Em alguns relatos esses comentários indicavam que já havia alguma coisa diferente no comportamento do doente desde a infância. Em outros casos, os comentários contrastavam o comportamento antes e depois da doença. Portanto, esses conhecimentos sobre a infância dos doentes se tornaram importante neste momento, pois permitiram compreender melhor como cada família construiu o processo de ajustamento.

Identificamos quatro tipos de relatos sobre a infância dos doentes. O primeiro tipo foi aquele em que os familiares descreveram o familiar que adoeceu como uma pessoa normal, sociável e alegre desde a infância até adolescência, período em que apareceu a doença sem ter relação com algum fator desencadeante. No segundo tipo de relato, o doente também foi descrito como alegre, mas o aparecimento do adoecimento é associado a algum fator desencadeante. O terceiro tipo de relato é aquele em que o doente teve alguma doença biológica ou dificuldade durante a sua infância (hipóxia no nascimento, hepatite e necessidades básicas) a qual teria sido a causa da doença atual. No quarto tipo de relato o doente foi descrito como uma criança isolada, tímida, com dificuldade de relacionamento interpessoal e com comportamentos agressivos, os quais se intensificaram com o adoecimento.

Após retomarem a infância e a adolescência do familiar, os participantes contaram como ocorreu o processo de adoecimento. A análise dos relatos permitiu delinear três momentos importantes: percebendo a mudança, diagnóstico e início do tratamento, e seguindo em frente.

\subsubsection{Percebendo a mudança}

Esta fase teve inicio quando o doente começou apresentar mudanças de comportamento. As mudanças relatadas variaram entre alterações de humor, de relacionamento e comportamento. O familiar deixou de sair com amigos e primos, ficava mais tempo sozinho no quarto, contava histórias que não ocorreram ou negava comportamentos 
realizados, tinha atitudes infantis como não controlar os esfíncteres, pensamentos persecutórios, interrupção dos estudos e comportamentos agressivos.

“Mas aí a gente começou a notar que ele [doente] não estava muito bom da cabeça nessa época mesmo. Ele ficava com medo de não sei quem ia pegar ele, se tinha um cara dentro do guarda-roupa, desmontou o guarda-roupa inteirinho de madrugada, meu guardaroupa, ficava assim, tipo, com essas loucuras?” (Família 10)

“Foi assim, ele ficava só no quarto, fechado, deitado, se chamasse pra comer, comia se não, não comia e ele ficava deitado no sofá. Ai tinha que ficar oferecendo comida. Mandar ficar tomando banho. E quanto ele dava de fazer xixi, nada, já tinha mijado tudo no short." ((Família 06)

“Ah, foi com 16 anos e meio que ele começou a ficar doente, que ele não queria mais estudar. Foi no final do terceiro colegial que ele começou a apresentar choro, não queria ir à escola, que ele estudava a noite. E ficava mais deitado, no quarto, ele ficava mais no quarto, deitado. E, ah, às vezes ele ficava agressivo [...]” (Família 23)

Alguns entrevistados relataram que no início não perceberam a mudança de comportamento porque estavam passando por um momento estressante, como a separação do casamento, por exemplo.

“[...] eu tava passando por uma crise no meu casamento, tava assim brigando muito com meu marido, e ele sempre falava pra mim que tinha medo de eu me separar, que tinha medo de eu me separar, tinha muito medo de eu me separar, eu mais meu marido, o pai dele. Mas, eu estava naquela crise e a crise cada vez piorava meu casamento, e eu não percebi muito porque eu tava meio assim envolvida, tava com depressão e depois eu demorei a custar a perceber que ele tava começando a ficar diferente.” (Família 01)

Para alguns familiares não havia explicações para as mudanças de comportamentos. Eles relataram que perceberam a mudança, porém acreditavam que era característica da adolescência, tais como: atitude para chamar atenção dos pais e familiares, rebeldia, construção de identidade e necessidade de liberdade. Em alguns casos os participantes referiram que essas alterações apareceram de maneira abrupta e evoluíram para os sintomas 
da doença, como alucinação, delírios, sexualidade exacerbada e comportamentos persecutórios.

"Eu acho assim, que no inicio foi assim, um pouco complicado. Quer dizer, aparentemente tudo bem estruturado, bonitinho, e de uma hora pra outra, como se tivesse, como se fosse um iceberg. Aparentemente tava apenas passando por todos aqueles conflitos da adolescência, minha irmã tava, ela tinha, 15 anos né? Mais ou menos isso? 15 a 16 anos. [...] 15 a 16 anos. Era um pouco rebelde, a gente achava que ela era um pouco mimada [...] (Família 19)

“A gente achava que era da idade, que ia sumir, era normal e um só pesadelo que íamos passar.” (Família 02)

“Mas antes era tudo normal. Antes num tinha nada dessas coisas não. Até os 25 anos ele não deu trabalho. Dos 25 anos pra cá que eu reparei que ele ficou ruim de repente. [...] Eu até fiquei boba de vê, né, como ele começo a fica doente de repente, aí eu fiquei boba. Foi assim de repente, ele encolheu tudo os braços assim, encolheu a perna, o coração dele batia bastante, quando ele começo a dá outros trabalhos já, né.” (Família 09)

“Olha a ela na verdade a doença dela veio assim sem a gente perceber. De repente ela começou a ter umas visões, ela começou a dizer que ouvia as coisas e começou a dizer coisas que não tinha sentido. Foi ai que nos percebemos que ela não estava bem, ela assim do nada começou a dizer coisa que não tinha fundamento então nos ficamos um pouco preocupado, foi ai que começou a doença da dela.” (Família 26)

Em alguns casos, a mudança de comportamento mais presente, foi relacionada ao uso de drogas. Os jovens deixaram de trabalhar, saíram da rotina, abandonaram os estudos, começaram a relacionar-se com pessoas estranhas à família e tornaram-se isolados. Alguns ficaram agressivos. Após um tempo, começaram a apresentar sintomas da doença, como persecutoridade, alucinações e delírios. Em todos os casos relatados a família explicava a mudança de comportamento como conseqüência do uso de drogas.

“[...] eles mexiam com drogas também, né. Aí acho que um dia ele falou assim, né, acho que eu quero experimentar. Acho que era maconha, era maconha, não sei. 'Eu quero 
experimentar, vocês são animados, vocês namoram, tal e eu sou muito tímido, eu queria arrumar uma namorada'. Aí esse rapaz falou, 'então eu vou te dar uma coisa'. [...] 'Eu vou te dar um negocio'. Em prazo de dois dias, três dias ele virou bicho. Dois dias só. Aí pronto, não arrumou namorada, não arrumou mais nada. Aí ele ficou mais ou menos quais um mês. Não queria voltar pra casa. Ele ficou na casa desse amigo que deu [...]” (Família 08)

“[...] só que ele usava droga né, ele começou a usar droga bem cedo e usava só maconha né, quando ele foi morar com a gente, no meu bairro, ele começou a andar com uns caras assim mais né, e começou a usar crack, ai ele começou a ficar assim, viciou mesmo nas drogas né, é, viciou assim [...]”"(Família 10)

"Era uma pessoa comunicativa, brincava com todo mundo. [...] Aí a amizade o levou a se aconchegar mais na favela, que é lá no brejo e daí ele começou a usar o craque. Ele usava pouco, mas daí ele ficou viciado e passou a usar sempre, diariamente, toda hora, né, e não conseguia mais ficar sem. Parou de trabalhar, ficou desmotivado e só ficava dentro de casa. Aí às vezes ele saia pra rua pra arrumar dinheiro, pra fumar. [...] é, no começo... Porque eu num sabia se ele fingia, se ele tava assim por causa da droga, se ele tava doente mesmo, sabe, a gente num sabia certo, né. Aí eu falava assim, ah, se ele parar de usa a droga ele fica normal, quem sabe ele ta assim porque ele usa droga, né. Ou ele ta fingindo [...]” (Família 12)

Em outros relatos o familiar doente já tinha algum problema desde a infância, como dificuldade de relacionamento e de aprendizado, era tímido, e/ou isolado, triste, nervoso e até agressivo. Assim, os familiares acreditavam que, no inicio, eram estas dificuldades que estavam influenciando no comportamento do ente querido naquele momento.

“Ah não, desde pequeno eu já sabia que ele não era certo. Alguma coisa tinha. Porque ele sempre foi sozinho. A única amiga dele que ele tem sou eu.” (Família 03)

“[...] a minha irmã desde pequena sempre foi uma criança assim, sempre problemática, ela nunca aprendeu a lê, ela nunca aprendeu a escrever, ela sempre teve que passar desde pequena, desde os sete anos, com psicólogos. Aí a minha mãe a colocou na classe especial, né, porque era diferente das outras crianças né, e que ela não se adaptava a ler nem a escrever.” (Família 05) 
“Aí começou a fase dele de escola, aí ele não ia bem na escola, que ele não adapta muito. Conforme ele foi crescendo ele foi ficando nervoso, assim, dava nervoso nele. Aí, só que assim, eu achava que era coisa de criança né. Aí ele foi crescendo, crescendo, aí chegou um tempo que ele foi ficando mais agressivo. Assim, em casa, com os, com os, ele sempre ficava nervoso, batia, foi aonde eu procurei um médico.” (Família 25)

A crença religiosa também apareceu como uma explicação para as mudanças de comportamentos observadas. A família, muito religiosa, acreditava que as mudanças de comportamentos observadas em seu familiar era devido um espírito que estaria possuindo o corpo do familiar doente.

“E no começo por nós sermos evangélicos, eu estava associando aquela situação, aquele comportamento, como se fosse algum espírito ou alguma coisa contrária.” (Família 02)

“Então, foi que começou meu marido que é mais assim, da religião espírita começou achar que era essas coisas que começou quando ela começou a freqüentar mais a religião [...]” (Família 21)

Como podemos observar nos exemplos acima, as mudanças de comportamento foram percebidas de alguma maneira. Porém, neste momento inicial, não se explicava às mudanças de comportamento como um sintoma de doença. As explicações variavam entre comportamentos da adolescência, crença, uso de drogas e características desde a infância. Somente com a intensificação e não resolução dos sintomas, a família começou a discutir se aquela mudança não seria uma doença e se a procura de um serviço de saúde não seria pertinente.

“[...] ele teve uma crise maior, até foi a pior de todas, com 18 anos, foi onde eu falei que iria trazer ele par cá e ver uma tratamento pra ele e achar o que ele tinha [...]” (Família 02)

“[...] ai eu falei porque que ele não saia mais, os colega dele chamava ele na porta e ele falava que não ia, ai eu falei: 'o que esta acontecendo?', 'porque ta enrolando minha 
língua', eu falei, vamos no médico, ta com problema na língua, vamos vê o que é.” (Família 01)

"Aí ele foi crescendo, crescendo, aí chegou um tempo que ele foi ficando mais agressivo. Assim, em casa, com os, com os, ele sempre ficava nervoso, batia, foi aonde eu procurei um médico. [...] antes ele ficava agressivo, mas assim, ele tacava um copo, chutava igual a alguns da família que é nervoso, chuta uma cadeira, e tal. Mas o dia que ele ficou bem nervoso, que ele quebrou uma televisão, uma televisão pequena que o pai dele tinha e tacou pedra na janela, aí eu o levei pro Cuibá.” (Família 25)

Em algumas famílias, o familiar entrevistado referiu que a percepção da mudança de comportamento foi de um familiar que não convivia diariamente com a família. Foi esse familiar quem questionou se a alteração de comportamento existente não poderia ser sintomas de uma possível doença. Talvez os familiares que conviviam mais próximo ao adoecimento não acreditavam em um possível adoecimento de seu ente querido. Enquanto que os familiares mais distantes dos conflitos da família perceberam as mudanças de uma maneira mais racional e assim, questionaram a necessidade de ajuda. Tal observação foi para algumas famílias o ponto de partida para o inicio do questionamento e com isso, a procura de ajuda.

“Ai minha irmã falou - 'M., leva ele [filho doente] na saúde mental que Serrana tem, né?’ Ai levei [mãe do doente] na saúde mental, passou com o medico lá e começou a conversar com ele.” (Família 06)

"E minhas irmãs mais velhas falavam: 'o seu filho parece que ta ficando diferente, você não ta achando?'” (Família 11)

“Então, quando começou né, minha irmã que observou, ela falou assim: 'parece que esse menino tem algum problema'.” (Família 13)

Após algumas considerações/discussões entre os membros da família, chegou-se à decisão de procurar um profissional de saúde. Os profissionais procurados inicialmente foram fisioterapeutas, psicólogos, fonoaudiólogos e médicos (neurologistas e psiquiatras). Geralmente a escolha do profissional estava relacionada à queixa principal do doente, como por exemplo, procurou-se um fonoaudiólogo porque o filho começou a usar uma voz estranha 
para falar. Mesmo quando a família procurou um psiquiatra no inicio não se falou em esquizofrenia. Segundo os relatos, os médicos afirmavam que era depressão, ansiedade, ou mesmo características da adolescência.

“[...] mas só que não chegou assim a ter esse diagnostico. Começou com um quadro depressivo. [...] O primeiro psiquiatra dele é, tratou dele como uma depressão mesmo. Uma depressão forte tal, pra você ter idéia [...]” (Família 11)

“Ele começou a fazer para depressão, não tava assim, atacou a cabeça dele, atacou a mente. Então ele tinha a depressão, mas tomava os remédios e ficava normal.” (Família 24)

"Aí o Dr. falou que era, num sei, parece que era ansiedade. Isso, ansiedade, num sei fala direito [...]" (Família 09)

Para reafirmar que o serviço de saúde mental também não identificou as mudanças de comrtamento como algo grave, uma mãe conta que quando procurou o serviço de saúde mental, a consulta de seu filho não foi marcada imediatamente.

"Mas eles marcou a consulta dele lá pra lonjão, achou que era uma frescurite, uma depressaozinha à toa, 18 anos, achou que era bobeira.” (Família 01)

Com o passar do tempo, mesmo que já iniciando tratamento com psiquiatra, as mudanças de comportamento evoluíram para um surto psicótico. A família reconheceu então que já não tinha condições de lidar sozinha com o problema e procurou ou foi encaminhada para serviço especializado. Nesse momento teve início a próxima fase identificada neste estudo, a fase de diagnóstico e início do tratamento.

“Até que foi um dia que o médico falou: 'nos temos que interna pra gente vê que esse remédio não ta dando certo, pra passar pra outro remédio, que é o clozapina.' [...] 'Você não tem cirurgia pra ficar branco, você precisa tratar da mente'. Que tava com esse problema, esse problema dele era esquizofrenia, que precisava tratar.” (Família 11) 


\section{Discussão}

Como podemos observar os familiares perceberam mudanças de comportamento em seu familiar. No início, eles acreditavam que essas mudanças eram típicas da adolescência, decorrentes ao uso de drogas, questões relacionadas à crença/religião ou uma exacerbação de algum problema existente desde a infância.

A questão da adolescência é muito importante nesta fase. Mesmo que os familiares deste estudo explicaram as mudanças do jovem através de características da infância ou devido ao uso de drogas, a família estava vivenciando, junto com seu familiar, a fase da adolescência. Por isso, em todos os relatos desta pesquisa houve alguma referência ao período da adolescência.

Milliken (2001), Assumpção Jr. e Kuczynski (1999), Karp e Tanarugsachock (2000) e Pejlert (2001), também obtiveram relatos de pais de doentes mentais que informavam que eles não reconheceram a mudança de comportamento de seus filhos adolescentes como um possível adoecimento no início. Esses pais também acreditavam que os adolescentes não estavam conseguindo lidar socialmente com a liberdade e independência que lhes eram concedidas pela família. Viam como atitudes rebeldes, infantis e deterioradas, extrapolando os limites que ainda lhes eram dados. A família acabava por tolerar os comportamentos do filho adoecido, acreditando que eram típicas do período de amadurecimento.

Milliken (2001) e Assumpção Jr. e Kuczynski (1999) também explicaram em seus estudos, este estado de tolerância adotado pelos pais no inicio do adoecimento. Isto ocorre porque as mudanças que aparecem são percebidas pelos pais como um dos desafios da adolescência, tanto para eles como para os seus jovens. As autoras salientam que a adolescência é uma fase de transição da infância para a vida adulta, caracterizado por mudanças biológicas, emocionais e socioculturais rápidas no jovem, e que necessitam de uma reorganização familiar. A família se organiza para se ajustar a esse novo evento, estabelecendo um relacionamento caracterizado pela diminuição da supervisão e aumento da autonomia e independência do jovem. Os pais passam de protetores a preparadores, ajudando seus filhos na maturação de questões sociais e sexuais.

Assim, a perspectiva dos pais é que seus filhos se tornem cada vez mais independentes e autônomos, terminem os estudos, adquiram independência financeira, assumam novos relacionamentos e constituam uma nova família. Por isso, a mudança de comportamento do adolescente pode ser entendida como um desafio para os pais, uma atitude do adolescente que exige tolerância dos pais como forma de promover o amadurecimento do jovem. Os pais se baseiam nos sonhos, aspirações que suas crianças demonstraram durante seu crescimento, 
comportamentos anteriores e personalidades. Portanto, pode-se dizer que pais de adolescentes e jovens adultos estão antecipando a liberdade de seus jovens, quando toleram os desafios da adolescência (ASSUMPÇÃO JR.; KUCZYNSKI, 1999; MILLIKEN, 2001).

Outro aspecto que deve ser salientado nesta pesquisa diz respeito ao uso de drogas. Em muitos dos relatos desta pesquisa a mudança de comportamento inicial refere-se ao uso de drogas. Os familiares entrevistados nas pesquisas de Milliken e Northcott (2003), também referiram que no inicio do adoecimento as mudanças de comportamento de seus filhos estavam relacionadas ao uso de drogas. Segundo esses pais, seus filhos passaram a relacionarse com grupos de riscos, permanecendo maior tempo nas ruas e envolvendo-se muitas vezes com a polícia.

Embora o uso de drogas possa ser compreendido como um dos desafios da adolescência, esta condição representa dois problemas importantes. De um lado o estigma social do "usuário de droga” pode atrasar a procura por ajuda profissional conforme salientado por Milliken e Northcott (2003). De outro lado, se o problema de uso de droga não for tratado também ele poderá se tornar uma co-morbidade que influencia negativamente o desenvolvimento do doente.

Em nossos dados também observamos que alguns familiares retomam características previas de seu familiar doente como uma explicação para os comportamentos apresentados. Assim como neste estudo, os familiares entrevistados na pesquisa de Muhlbauer (2002), também relacionaram as mudanças de comportamentos de seus filhos à características e deficiências existentes desde a infância, tais como: dificuldades de memória e concentração, atitudes violentas, problemas com questões e relacionamentos sociais, dificuldade em administrar dinheiro, de enfrentar períodos de estresse e de mudanças.

Com o passar do tempo o adoecimento evoluiu para um surto psicótico. A família reconheceu então que já não tinha condições de lidar sozinha com o problema e procurou ou foi encaminhada para serviço especializado. Nesse momento teve início à próxima fase identificada neste estudo, a fase de diagnóstico e início do tratamento.

Jungbauer et al. (2004), Karp e Tanarugsachock (2000) e Milliken e Northcott (2003) que também observaram nos dos relatos dos familiares participantes de suas pesquisas que com a intensificação nos sintomas e a ocorrência do primeiro surto psicótico, os pais relutantemente admitiram a possibilidade de uma doença mental e entraram no sistema de saúde mental. 


\subsubsection{Diagnóstico e início do tratamento}

À medida que o adoecimento evoluiu para um quadro agudo e a família reconheceu que não conseguia resolver sozinha o problema de mudança de comportamento do familiar, houve a entrada no sistema de saúde mental, iniciando o segundo momento identificado nesta pesquisa, o momento do “diagnostico e início do tratamento”.

Com o familiar em quadro agudo da esquizofrenia, a família vivenciou um período intenso marcado por idas freqüentes ao serviço de saúde, culminando com a primeira internação psiquiátrica. Em muitos casos o doente não aceitava a medicação e em outros a medicação prescrita não fazia efeito. É nesse contexto de procura do médico e internações que a família recebeu o diagnóstico de esquizofrenia.

“Ele voltou, mas já começaram já tava as crises nele. Aí logo que ele veio pra cá já começou a dar aquelas crises dele ficar, assim, igual bicho, olho vermelho, como uma brasa. Começou a ficar pelado, queria sair pelado na rua. Aí nos chamou a ambulância, aí começou vir aqui no postinho, né, na Cuiabá. Aí vinha né, dava uma injeção nele, um remédio, voltava pra casa. Aí por fim nos, a semana toda chamando a ambulância, falamos, nos não temos a condição de ficar com o meu filho em casa desse jeito. Aí voltou de novo no posto de saúde aí levou para um pronto atendimento e deste levou para o hospital psiquiátrico, já todo amarrado [...]” (Família 08)

“[...] o médico passou medicação, só que chegou em casa o meu filho não aceitou medicação. Não quis tomar os remédios. Aí ele foi mexendo muito com os vizinhos mesmo, aí teve que internar, teve que internar ele." (Família 23)

“Aí o médico pegou e falou que ele tinha esquizofrenia. Aí eles começaram o tratamento nele.” (Família 25).

Os familiares relataram um grande impacto ao receberem o diagnóstico de esquizofrenia. Palavras como susto e choque foram usadas para descreverem este impacto. A idéia do adoecimento do ente querido e de uma doença psiquiátrica, bem como o não conhecimento desta, gerou um sentimento intenso de desespero em todos os familiares. 
"E ai, na hora eu levei um choque, mas tipo, eu aceitei. Acho que tem que passar, vamos passar, né? Mas eu daquele dia em diante eu já reconhecia, eu já falava pra minha família o que ele tinha, né? E a gente começou a ver as coisas com esquizofrenia, né? [...] Aceitou assim, todo mundo assustado, né? [...] Um choque muito grande. [...] Ela não fica só nisso daí, tipo assim, você lembra logo que louco, que antes era assim, né? Ou era louco, ou era doido. [...] É porque você traz a imagem de um louco. Ai ela traz muita coisa dentro de casa que associa.” (Família 11)

"Foi um choque pra todo mundo, porque ele sempre foi um rapaz bem saudável, trabalhava. Então, foi um choque terrível pra família. Todo mundo ficou assustado, entendeu? Outros choravam. Mas em geral todo mundo ficou bem espantado.” (Família 12)

Muitos entrevistados relataram que não conheciam a doença e que se sentiam assustados.

“[...] assim, todo mundo assustado, né? Porque todo mundo num sabia do era esquizofrenia. Que era não, não sabia quais eram as conseqüência [...] porque eu não tinha noção da gravidade de que podia vir acontecer.” (Família 11)

“Nunca eu ouvi falar desta doença.” (Família 18)

“Ah, primeiro assim, eu levei um susto né. Por que eu não, não conhecia essas doenças, né. Depois assim, eu chorei muito.” (Família 21)

Embora tivessem referido que não conheciam a doença, os relatos indicaram um estigma associado a ela. Relataram que a revelação do diagnóstico proporcionou sentimentos de culpa, desespero e sofrimento ao verificar que aqueles comportamentos eram indicativos de doença mental, geralmente chamada de loucura. Alguns referiram até adoecerem neste período.

"Esse nome para mim era uma coisa muito feia, esse nome dessa doença, nunca imaginava que um dia meu filho pudesse estar com essa doença. [...] Mas só que a sociedade e muito ruim, fica incriminando as pessoas, a gente se sente a menos por causa de uma coisa dessa família, a as pessoas não entendem que o meu filho passa ou então falam que é 
preguiça de trabalhar ou nós que educamos errado, então a sociedade e muito difícil." (Família 02)

“A D., ela era adolescente, ela chorava junto comigo, num tinha como às vezes eu não chorar, mesmo quando acha que você ta sofrendo muito, mesmo quando você vai ter seus momentos intimo com Deus, com sua devoção, você chora quando você ta com um problema. [...] Ai ficou mais difícil ainda pra você pensar, o sentimento que a mãe tem né? É uma dor muito grande. [...] Impotente, aliás, diante a uma situação dessas. Porque você não sabe o que fazer, é difícil demais.” (Família 11)

“Mas me deu uma depressão dura quando ele ficou doente, que eu passei mal, nossa. Passei que nem comia, nem comia porque nunca tinha acontecido nada com ele, né. Aí eu fiquei muito ruim, nossa senhora. Passei mal mesmo de ver o sofrimento dele. Acho que eu sofria mais ainda. Nossa, sofria mais ainda quando ele tava, quando ele ficou ruim mesmo, nossa, passei muito mal. Deu-me aquela depressão, nossa senhora. Muito ruim demais. Depressão é uma coisa ruim, né?” (Família 09)

Outros relatos indicaram sentimentos de culpa pela doença do filho, principalmente pelas mães. Referiram acreditar que, por terem dado a luz a essas crianças, por guiarem o seu desenvolvimento e por não cuidarem corretamente deles na adolescência, tem grande responsabilidade sobre o adoecimento.

"Mas que a minha família fala que eu e meu marido que somos culpados né. De ele mexer com isso. Eu falo né, porque que nos somos culpados. [...] Mas minha família culpa que foi a droga. Que não era pra nos aceitar o meu filho dentro de casa [...]” (Família 08)

“O meu filho não, eu fico com pena dele, poxa, fui eu né. Eu que o pus no mundo com essa doença né, onde já se viu isso. Se eu soubesse, talvez né, teria evitado né. Eu não me sinto bem vendo sofrer né, sofrendo com essa doença, né. [...] Ah, eu me sinto, porque né, se eu não tivesse tido ele, né. Se eu não tivesse conhecido o meu marido, se não tivesse tido ele. Então eu e sinto culpada em relação a ele, dele estar assim.” (Família 18)

“[...] todo mundo começou a se culpar, principalmente meu pai e minha mãe. [...] eu que já era formada, que já era enfermeira, eu mesma falei gente, eu me sentia na obrigação 
de ser forte. Eu falei assim, 'gente, como que eu, quanto enfermeira, vou conseguir estar, assim, dando esse suporte?’ Porque nem eu, eu mesma tive.” (Família 19)

Outros sentimentos foram relatados nessa fase. O medo dos sintomas e comportamentos, principalmente os agressivos e de risco, e a incerteza sobre o prognostico da doença.

“Ai começou o tratamento, mas o problema é que era o seguinte: a gente tinha medo de dormir, medo de qualquer barulho que acontecia dentro de casa, porque a gente achava que era ele em crise, a minha menina passou por esse problema todo de ter medo." (Família 02)

“É, é eu tive que abandonar a minha casa por causa dele, né, assim, porque ele ia lá, dava trabalho, eu tive que morar com a minha sogra, morei com a minha sogra, quer vê, acho que quase um ano eu me lembro, [...] eu tinha medo de ele ir lá, querer agredir a gente, porque a gente, tipo, que pôs ele pra mora com o meu pai, sabe, assim, na cabecinha dele ele ficar com raiva, com ódio da gente, porque a gente, nunca se sabe, né.” (Família 10)

"E a gente tinha medo que na hora ele ia mexer no relógio da força, entendeu? Ele mexia muitas vezes, então a gente ficava preocupado, com medo né.” (Família 23)

Uma questão importante também observada nos relatos foi a dificuldade de convivência com os sintomas da doença. Houve o distanciamento de alguns familiares e de amigos em relação ao doente. A própria família também se distanciou da sociedade, devido seu cansaço e na tentativa de evitar viver situações desagradáveis e de sofrimento.

"Ele ia à casa de um, ninguém ligava, todo mundo saia de perto né, excluía ele, assim. Tinha uma festa, ninguém o chamava de medo dele bebe né.” (Família 18)

“Em relação aquela época, eu acho que é que nem a E. falou, tem muito dos amigos dela que eles acabaram se afastando muito pelo próprio comportamento dela. Ela às vezes ela ta bem, outra hora ela acaba sendo um pouco, até, agressiva, em tão muitos dos amigos dela acabaram se afastando né.” (Família 19) 
“Isso, o D. em surto e meu outro filho com medo do irmão dentro de casa, ele praticamente casou pra sair de dentro de casa, mas gostava da moça, mas não vamos falar assim, não vamos atribuir tudo a isso não, ele gostava da moça, mas com medo do irmão vivendo dentro de casa, aquela coisa que você não sabia o que tava acontecendo, quem não quer fugir dessa situação? Então, quer dizer, ai o meu outro filho casou [...]” (Família 11)

"Um dos meus filhos que é o mais velho, que hoje é ferroviário, chegou um tempo a morar fora de casa porque ele não conseguia conviver com as manias, com as manias de tomar banho, de tomar seis, sete banho.” (Família 16)

Dúvidas sobre a veracidade do diagnostico também foram relatadas. Os familiares questionavam constantemente se o que os membros estavam apresentando eram sintomas da doença, se eram devido ao uso de drogas ou características da adolescência para chamarem atenção dos demais familiares. Além do não conhecimento da doença, podemos observar pelos relatos, que essas dúvidas surgiram também devido à dificuldade de um diagnostico ser estabelecido e do questionamento de o familiar doente ter sido sempre uma pessoa normal.

“[...] é, no começo, porque eu num sabia se ele fingia, se ele tava assim por causa da droga, se ele tava doente mesmo, sabe, a gente num sabia certo, né. Aí eu falava assim, ah, se ele parar de usa a droga ele fica normal, quem sabe ele ta assim porque ele usa droga, né. Ou ele ta fingindo que ele ta louco só pra gente fica com dó, volta à mora comigo, sabe assim [...] A minha cunhada fala que ele é louco nada, que ele se faz de doente, que nós é boba de te dó dele, de cuida dele, no caso eu e minha tia, que a gente num tinha que ir lá, que ele é louco nada, ele se faz de louco. Mas eu acho que ele tem problema realmente, sabe? Ele num se faz de doente." (Família 10)

“Mas até então eu não aceitava que ela tinha esquizofrenia, porque, caso, porque eu acho que ela passou por três grupos de médicos. Um não consegue e um passa pro outro. $\mathrm{Na}$ época que deu esse diagnostico, eu senti que, tipo assim, depois de quatro meses, era a terceira equipe, então eles tinham que fechar alguma coisa. Porque era exame atrás de exame, exame atrás de exame, medicação atrás de medicação, nunca se tinha uma resposta. Eu fiquei meio assim, sabe, quando ela saiu, meio assim, "não, você tem que ir embora, vamos fechar com isso e pronto”. (Família 19 / familiar 01) 
“Eu sabia disso, mas a minha família não né. Tanto é que todo mundo falava assim, 'não, ela não tem esquizofrenia, não isso aí'. Aquela fase de negação eu achei assim, que ficou um período muito mais, menor.” (Família 19 / familiar 02)

Quando os relatos dos familiares chegaram neste ponto da história, muitos fizeram afirmações pesarosas sobre o filho doente. Que eram pessoas boas, estudiosas, trabalhadoras, que não davam trabalho. Estes relatos sugerem uma percepção de que esta pessoa "normal” deixou de existir.

"Puxa vida né, uma doença dessas e logo para ele, que é uma melhor pessoa. Ele é bom, ele não é ruim.” (Família 18)

“E como será isso, né? Na verdade eu já não penso, será que já não nasce com esse problema? É isso?” (Família 06)

“Eu num sei se isso vem de infância, da família, ele uso droga que tipo, que complico, piorou, ou se foi devido as droga mesmo, isso aí eu num sei. (...) Acho que foi devido as droga ou devido a isso que eu te falei, né, meu pai tem problema, o irmão dele tem, um tio meu também tem.” (Família 10)

“É, mas eu acho que ajudou muito com a faculdade. [...] É, eu acho que foi por causa da faculdade. [...] Então, eu ficava, muito, com esperança, achando que ela era normal. Ela tinha tanta vontade de fazer as coisas, tanta vontade de estudar. E porque tinha acontecido isso? Eu ficava me perguntando.” (Família 21)

"Até que foi um dia que o médico falou: 'nos temos que interna pra gente vê que esse remédio não ta dando certo, pra passar pra outro remédio, que é o clozapina.' [...] 'Você não tem cirurgia pra ficar branco, você precisa tratar da mente’. Que tava com esse problema, esse problema dele era esquizofrenia, que precisava tratar.” (Família 11)

Nessa fase, a família também referiu que introduziu cuidados com o medicamento prescritos, pois seus doentes muitas vezes tinham dificuldade para seguir a prescrição médica. Assim, a família que no início pensava que tinha que ser tolerante em relação aos comportamentos diferentes do adolescente, retomou a posição de vigilância. 
“Então, eu tinha que ficar observando se ele não jogava o remédio fora, tinha que ta de olho para ver se ele não tava jogando o remédio fora, porque se ele não tava tomando ele surtava.” (Família 01)

"Foi a irmã dela que viu. Ela disse que ela tava jogando remédio fora. Ela tentou por no ralo do lavatório e parou. E ela viu jogando. Aí foi onde que, né, que eu tenho que fazer engolir e não vou deixar você ir no banheiro bom um bom tempo. Você vai ter que, mas derreter é pior, meio comprimido derretido é pior, né. Aí foi que, mas sempre assim, nervosa. Sempre sem paciência demais.” (Família 21)

Ao entrar em contato com o diagnóstico e com o tratamento, muitos familiares relataram que começaram a buscar mais informações sobre a esquizofrenia. Eles queriam conhecer mais sobre a doença e assim compreender melhor o que a família estava vivenciando. Essa busca de conhecimento foi feita diretamente pela família, através da internet, revistas, reportagens. Além de leituras, as famílias também receberam informações dos profissionais de saúde.

"Sempre eu estava lendo as reportagens, sempre lendo no computador, pra saber sobre esquizofrenia, você entende? Sempre alguém dizia, olha esquizofrênico pode acontecer isso, aquilo, pode acontecer aquilo outro. Então, tava sempre procurando saber, me informando mais, o que podia acontecer, o que eu podia estar atenta [...] Nossa, eu queria matar ele! Falava que a vida dele era isso, era aquilo, não agüentava. Agora eu entendo, faz parte, isso tudo faz parte, né. Agora eu entendo,mas antes eu não entendia porque eu achava, imagina, porque isso, porque aquilo, ficando doido. Porque eu não entendia, mas depois eu fui entendendo, porque minha prima assim começou a entrar na internet, ver o que era esquizofrenia, pra gente entender o que era.” (Família 01)

“E, aí depois eu fui, fui aceitando a consciência do que tava acontecendo. O médico me explicando a doença.” (Família 21)

Assim, com o tempo, o doente vai apresentando respostas ao tratamento e a família vai tentando compreender o contexto do processo de adoecimento que se encontra. Com isso, caminhamos para próximo momento neste trabalho encontrado que denominamos "seguindo em frente”. 


\section{Discussão}

Como observado na descrição dos dados acima, a família percebeu que não poderia ajudar o seu familiar que estava adoecendo. Com o aumento da intensidade dos sintomas e o surto psicótico, a família procurou um serviço de saúde especializado. E foi nesse momento que se falou pela primeira vez em um possível diagnóstico de uma doença mental, a esquizofrenia. Como descrito, foi um período cheio de idas ao serviço e, em alguns casos, ocorreu à primeira internação.

Mesmo profissionais de saúde têm a dificuldade de, no inicio das mudanças, fazerem a relação entre as características apresentadas e o diagnóstico de esquizofrenia. Karp e Tanarugsachock (2000) discutem a questão da dificuldade do diagnostico de esquizofrenia. Eles defendem a idéia que o diagnóstico de uma doença mental envolve decisões sociais e políticas e não apenas médicas. O diagnóstico estabelece um relacionamento entre a família e o serviço de saúde. É a partir deste relacionamento que a família recebe informações básicas da doença (MUHLBAUER, 2002).

Para Karp e Tanarugsachock (2000) a decisão de levar o familiar ao serviço de saúde é difícil para a família. Até esse momento, a família tentou manter o cuidado de seu familiar sem a necessidade de ajuda especializada. Essa decisão de procurar ajuda envolveu muitos sentimentos de perdas, duvidas e confusão para toda a família. Agora, sem alternativa, ela entrou no sistema de saúde.

Com o estabelecimento do diagnóstico, teve inicio de uma nova fase para a família. Na pesquisa de Pejlert (2001), algumas famílias descreveram este evento como se suas vidas tivessem sido divididas em dois períodos, antes do diagnóstico e após o diagnóstico da doença mental. Outras pesquisas que entrevistaram familiares de portadores de esquizofrenia também relataram que os entrevistados descreveram o momento do diagnóstico como cheio de sentimentos negativos, de perda, como se o seu familiar que existia antes do adoecimento tivesse morrido (MAULHBAUER, 2002; STEIN; WEMMERUS, 2001).

Em pesquisas existentes que estudam o processo de adoecimento pela esquizofrenia e a família, podemos encontrar relatos de familiares que preferiam não saber do real adoecimento do familiar. Para outras famílias, o estabelecimento de um diagnóstico foi visto como um alívio, porque trouxe respostas aos comportamentos do doente e criou novas expectativas (KARP; TANARUGSACHOCK, 2000; STEIN; WEMMERUS, 2001).

Assim como os resultados apresentados nesta pesquisa, as palavras choque e sustos também foram usados pela maioria das famílias participantes de estudos já existentes. Em todos os estudos, elas vêm acompanhadas pelo sentimento de perdas, tristeza, confusão, raiva 
e desespero em saberem que seu familiar sofre de doença mental. Sentimentos antes existentes são substituídos. Isto é, até o diagnóstico existiam sentimentos ríspidos as atitudes do doente, cheios de julgamento e desprezo. Após o diagnóstico, sentimentos de compaixão, esperança e compreensão são relatados (KARP; TANARUGSACHOCK, 2000; MILLIKEN, 2001; MILLIKEN; NORTHCOTT, 2003; PEJLERT, 2001).

Muitos familiares demonstraram em seus relatos que se sentem culpados pela doença do familiar, principalmente os pais, e procuraram constantemente justificativas para este adoecimento. Em outros estudos encontramos também o relato desses sentimentos. A crítica dos membros da família, principalmente dos pais, em relação a atitudes com o doente, o não conhecimento da doença, o possível componente genético e a desvalorização dos demais filhos em detrimento do cuidado do filho doente foram relatadas como as principais causas dos sentimentos de culpa (ASBRING, 2001; HARDEN, 2005; JUNGBAUER et al., 2002).

O não conhecimento da doença fez com que os familiares, desta e de outras pesquisas, referissem que vivenciaram a dúvida sobre a veracidade do diagnóstico e sobre a existência de uma doença real. Também fez com que questões de estigma deles mesmo e de outras pessoas fossem relatadas, além da busca constante de justificativas para o que estava acontecendo (MILLIKEN; NORTHCOTT, 2003; MUHLBAUER, 2002).

Estudos mostram que alguns familiares, confusos com o que vivenciavam, questionava-se constantemente se os comportamentos apresentados eram sintomas da doença. Isto ocorreu devido à família não ter conhecimento da doença, de seus sintomas, de sua complexidade e da dificuldade de tratamento. Aqui, referiu-se uma duvida baseada na esperança do erro no diagnóstico, da não veracidade do adoecimento e da não cronicidade da doença, isto é, a possibilidade de uma possível cura (MILLIKEN; NORTHCOTT, 2003; MUHLBAUER, 2002).

Os estudos podem mostrar que a falta de conhecimento também faz com que apareça o estigma da própria família e da sociedade perante o adoecimento do familiar. A dificuldade de conviver com a doença faz com que os familiares sintam-se incomodados com os possíveis julgamentos das demais pessoas. Com a vergonha dos comportamentos e sintomas do doente, a família se exclui da convivência social, vendo neste isolamento uma maneira de preservar o familiar doente e a ela mesma (KARP; TANARUGSACHOCK, 2000; MILLIKEN; NORTHCOTT, 2003; STEIN; WEMMERUS, 2001).

Outros estudos também descrevem que a busca de conhecimento sobre a doença de seu familiar e o inicio de um processo de aprendizagem faz com que a família comece a caracterizar os sinais e sintomas da doença, conseguindo organizar compromissos e tarefas, 
enfim, o reordenando o desenvolvimento funcional da família (JUNGBAUER et al., 2004; MILLIKEN; NORTHCOTT, 2003; MUHLBAUER, 2002). Milliken e Northcott (2003), em seu estudo, assim como nos dados desta pesquisa, referem que as informações sobre a doença, neste momento, são conseguidas a partir leituras relacionadas à doença.

\subsubsection{Seguindo em frente}

Passando a fase de choque e sentimentos perturbadores, a família reconhece a necessidade de aceitar a doença e cuidar do seu doente. Inicia-se o momento que nomeamos de "seguindo em frente”, por envolver uma série de tarefas necessárias para a família incluir a nova condição de ter um portador de doença mental em seu cotidiano.

O doente começou apresentar alguma melhora no quadro geral. Na opinião dos entrevistados esta melhora foi resultado do ajuste medicamentoso, da aceitação do tratamento pelo familiar doente e sua adesão ao tratamento farmacológico e ao apoio da família.

“Custou, mas dai foi aumentando a medicação dele, devagarzinho. Agora posso falar que ele está ótimo, entende? Em vista do que ele ficou, mas até chegar aqui começou com dezessete, ele está com vinte e um. Agora que eu posso falar que o G. está bom, entende [...] Porque eu sei que agora ele ta bom, você entende? Que ele toma o remédio direitinho, ele ta consciente que tem que tomar o remédio, ele ta consciente [...] Agora ele aceita o remédio, antes de trabalha, eu acordo ele na cama, dou café, depois dou o remédio que ele toma de manha, pra ele antes de trabalha.” (Família 01)

“Tá bom, tá melhorando, ta melhorando. Agora o pai dele tá mais contente, né. Nossa, o meu marido fala assim, 'Como ele melhorou de uns dias pra cá.' Assim, foi uma melhora, assim, de repente, você entendeu, bastante mesmo.” (Família 23)

Com o inicio da estabilização do quadro do doente, o retorno à normalidade começa a parecer mais plausível, e, portanto, mais esperado. O sentimento de esperança nessa fase é intenso. A busca da cura da doença é constante. A procura por terapias alternativas e crenças religiosas apareceram. Qualquer caminho que aponte na possibilidade do retorno a vida passada é tentado. 
"Queremos que ela saia, tenho a esperança que ela se sinta cada vez mais forte, por que volte a ser normal. Essa é a esperança que sempre temos, pedimos sempre a Deus, e nos vamos alcançar porque eu tenho fé.” (Família 26)

"Espero que o meu filho fique bom, né. Melhor, mais ainda e a gente pode deixar esse passado ruim pra trás, né. E cada vez que passa, fica mais longe, apesar de que to assim, meio deprimida, mas, também, não sou de ferro, mas graças a Deus, vai da tudo certo.” (Família 01)

"Eu não consigo mais ter prazer em nada nessa vida. Eu não consigo ver as coisas com muita expectativa assim, de pisar em algo concreto, eu tenho esperança que, ainda tenho esperança, de ter alguma coisa concreta assim, de que fique assim, que não piore, que se Deus quiser ele nunca mais vai ter surto. Porque na esquizofrenia o pior é o surto, né?” (Família 11)

"Porque eu acho assim, que até aconteceu até milagre de o F. hoje dar essa melhora. Porque o meu marido assim achava até que impossível o caso do F.. E eu falava, 'não L., não pode desanimar. Você não acredita em Deus? Tem que ter esperança que ele vai ficar bom." ” (Família 23)

Neste sentido da esperança a família começou a estimular o seu familiar a retomar a independência que tinha antes do adoecimento. Ele passou a ser estimulado a realizar algumas atividades rotineiras sozinho, como a administração de sua medicação, retorno médicos, saída de casa como ida a Igreja, participação em eventos familiares, realização de cursos, retorno ao trabalho, restabelecimento de grupos de amigos e mesmo manter-se sozinho em casa.

"Ele que tem que saber à hora dele ir buscar o remédio, a quantidade, o dia de tomar, o dia das consultas. [...] Ele vai ter que cuidar de tudo. Ele que, eu vou ter que treinar ele pra isso.” (Família 25)

Então é um, agora mesmo eu mandei ele ir na cidade, pegar o ônibus pra ir sozinho, agora que começou a ir na Igreja lá no centro, então eu peguei e fui só pra ver se ele ia. Ele chega do serviço, você toma banho e tal, e você vai na Igreja depois, 'ah, se o pai deixar eu vou'. Aí o meu marido deixou, ele foi direitinho, aí chegou lá na Igreja, ele ligou pro meu 
marido que tinha chegado, porque se não a gente fica preocupada, porque com esse problema que ele tem todos, a gente fica preocupada. Será que ele chegou, aí ele ligou pro meu marido dizendo que chegado lá na Igreja aí ele ficou sossegado.” (Família 13)

“Apesar de que agora que ele ta fazendo esse curso, ele fica o dia todo la, no começo eu sentia mais medo [...] agora eu fico despreocupada porque sei que ele tá la no curso e tá bem [...]” (Família 02)

“Agora que ele começou a trabalhar faz umas duas semanas, né. Já pegou mais amizade, rapaz que joga bola o chamou, pra jogar bola outro dia. Ele foi os amigos dele foi trazer ele em casa né. Mas ele ta mais, mais ele fala de namorada. Ele vai à Igreja né. Eu falo que ele tem que procurar uns amigos na Igreja, uns moços bons, né. Agora vamos ver né.” (Família 08)

"Aí quando foi ontem a minha mãe foi com a minha tia, que foi eles foram almoçar fora, na casa da minha família, aí eu virei pro meu irmão e falei: 'C . por que você não leva...', por que eu não tenho carta de carro, 'C., por que você não leva a nossa irmã na casa da tia pra ficar lá junto com a mãe, com a família, vai estar a D., tudo mundo lá'. Ele a pegou, levou, ficaram o dia inteiro lá, todo mundo, sabe. Eu senti que ontem, num domingo que eles passaram com a família, eu senti assim que o domingo pra eles foi bem." (Família 05)

“É, domingo eu tive uma experiência assim, 'olha, vamos no rancho, na beira do rio pardo, vai todo mundo. A senhora vai?' 'Vou!' 'E a C.?' 'Eu vou, mas lá vai ter uma cama?' Ele falou: 'Pêra aí que eu descubro'. Ligou pro dono do rancho e falou: 'Você tem uma cama e um colchão ou a gente tem que levar um colchonete, porque a minha irmã toma um remédio e aí ela precisa dormir uma hora pelo menos. "” (Família 16)

Com a melhora do doente e a aceitação da existência de uma doença, a família tem oportunidade de fazer arranjos que incluam o doente e seu restabelecimento, mas que também possam retomar as demandas de todos do grupo. Alguns retornam ao trabalho, outros ficam como cuidador principal. Uma nova rotina começou a ser organizada, baseada no cuidado do doente, suas necessidades, seu humor e promoção da tranqüilidade dos demais familiares. 
“É, agora ele dorme até uma hora, né, R., até uma hora, ou às vezes até meio-dia, ele dorme. Aí depois ele levanta, eu já deixo a comida pronta pra ele, já faço a comida, tudo, deixo pronto pra quando ele levanta já ta pronto, né? Já ta tudo prontinha já. Aí eu olho ele, fico olhando ele, né, fazer o que, num tem ninguém pra ajuda a olhar ele, aí eu mesmo, né. É fácil não.” (Família 09)

“Ele fica sozinho. Sabe, assim, né, quando saio demais eu deixo comida pronta, tudo. Às vezes ele come, às vezes não. Às vezes eu saio, eu deixo tudo arrumadinho, quando eu chego ta do mesmo jeito. Outra hora eu chego, ta tudo assim. Não tampa as panelas, nenhum dos dois, não tampa as panelas, na pia deixa os pratos com comida, se tiver algum ossinho, vai tudo dentro. A mesa fica cheia de formiga. Eles não tem aquela preocupação de limpeza, assim, né.” (Família 18)

Em todas as famílias, um cuidador principal foi estabelecido e os demais membros apareceram como auxiliar ou ausente. Na maior parte das famílias quem assume esse papel é um membro feminino. A mãe aparece em quase todas as famílias como protagonistas deste papel de cuidador.

Esse cuidador principal era responsável pelo cuidado integral do doente, como necessidades básicas, medicação, consultas médicas, comparecimento a exames de rotinas e retirada mensal de medicação. Eles deixaram de realizar atividades existentes antes do adoecimento, como trabalhar ou reestruturam seus horários. Quando eram responsáveis pelo trabalho doméstico, o organizavam para cuidado do familiar doente fossem sempre de principal importância.

“[...] eu parei de trabalhar. Se ele não tivesse esse problema, eu tava trabalhando. Eu trabalho porque eu gosto da minha profissão. Eu tive que parar, porque não tinha condição de levar as duas coisas. Eu não sou mais aquela pessoa de antes, eu tento ser perto dele.” (Família 11)

"Porque é muita coisa para pensar. Nossa muita preocupação de exame, dia de, dia de buscar, tirar sangue, buscar remédio. Pego remédio aqui, pego no posto, no dia que vai acabar se vai dar no sábado, você tem que ir à sexta, então, você tem que estar sempre assim, sempre alerta em tudo.” (Família 25) 
Com o tempo, houve inclusão de uma segunda pessoa no cuidado, e após isso, outros membros foram incluídos de maneira parcial. Alguns familiares se distanciaram do cuidado devido não conseguirem se envolver com a doença.

“Eu tenho uma filha que sempre, pra mim, me deu a mão, que essa é minha filha mais velha e ela que me ajudou nessa parte assim do irmão, porque meu marido foi embora." (Família 01)

“Quando eu preciso sair um pouco, alguma coisa e o pai também a gente recomenda e a irmã dela cuida direitinho, remédio, às vezes a gente precisa sair no horário de dar remédio e ela dá direitinho.” (Família 26)

“Então, o irmão dela é uma pessoa assim, ele não é muito de conversar com a V., mas ele ajuda. O que ele puder fazer ele ajuda sim.” (Família 05)

“Meio diferente eles é. Nenhum deles dá ajuda, não, nenhum deles ajuda. Nenhum. [...] Mais ninguém. Eu falei da médica, lá, tudo, da ajuda deles. Não ajuda em nada mesmo, tem que fala a verdade, né? [...] E é só eu e ele, só [...]” (Família 09)

“E a mãe dele assim, a mãe dele cuida dele direito, dá os remédios certinhos. É a única também que fica do lado dele, acompanha ele, porque os restantes dos irmãos uns trabalham, outros não querem nem saber, outros são doentes. [...] Uns se afastam, inventam desculpas que: ah estou trabalhando, não tenho tempo. Mas eles se afastam mesmo é por medo. [...] Por medo. Porque às vezes ele não reconhece ninguém quando ele ta em crise. Ele não reconhece ninguém, não respeita ninguém, xinga todo mundo, fica bastante exaltado[...] Eu ajudo a minha avó desde que começou entendeu. Desde o inicio da doença dele até hoje.” (Família 12)

“Minhas filhas mudaram um pouco, que elas não vão mais lá. Vão muito pouco, que ele chorava muito, elas não tinha paciência com ele. A irmã falava que não tinha paciência de ver ele daquele jeito, chorando." (Família 24)

Com o inicio da reorganização do núcleo familiar, os membros se estruturaram de maneira que nunca deixem o doente sozinho ou sem supervisão por um longo período, mesmo 
que indireta. Essa supervisão era realizada pelo cuidador principal, porém na ausência desses, outros membros a faziam, de modo que ela nunca deixe de ocorrer. O tratamento medicamentoso era a central preocupação.

“[...] se um sai, um fica, ou ele sai com o pai dele eu fico, ou sai todo mundo junto. Então, se eu vou pra igreja e eu fico uma hora e meia na igreja, ele pode chegar bem do culto, eu sinto bem deixar ele sozinho la uma hora e meia, mesmo sabendo que ele ta bem agora, mas eu não gosto mais de deixar ele sozinho, não gosto.” (Família 02)

“Agora ele ta melhor. Mas, precisa acompanhar ele, não pode deixar ele sozinho [...]” (Família 03)

“Às vezes quando ele ta bom eu deixo ele em casa, quando eu vejo que ele já ta bom, que passa um pouquinho melhor, ainda deixo. Mas eu venho logo, eu num vou assim, vou pra missa, fico lá uma hora, duas horas, mas já venho embora já.” (Família 09)

"Ele toma a quantidade certa, comigo olhando, mas ele faz tudo. Ele nunca deixou de tomar. Se passar da hora ele mesmo fala, 'cadê o remédio?’. Isso daí ele faz tudo certinho. Porque você que tem que dar os remédios, não pode esquecer.” (Família 25)

"Porque essa esquizofrenia tem que continuar o tratamento, não pode parar de tomar o remédio, então eu dou o remédio na mão dele antes de dormir [...]” (Família 01)

Até o momento foram apresentados dados relacionados com o sentimento de esperança presente no momento atual em que a família segue em frente. A seguir será apresentado outro sentimento também presente no momento atual. Trata-se do sentimento de medo.

O sentimento de medo aparece de maneira diferente nessa fase devido o inicio do aprendizado sobre a doença e a saída do quadro agudo da esquizofrenia. Aqui ele foi descrito como preocupações quanto ao futuro do familiar e quem se responsabilizará pelo seu cuidado, medo de recaídas e novos surtos psicóticos. 
“[...] a gente tem medo de uma recaída sabe, essas coisas assim. Por isso que eu te falo que eu falo assim, que não deixo a $P$. tomar o remédio porque a gente tem medo dela recair.” (Família 26)

"Medo de que ela tenha uma recaída e que ela não consiga voltar como ela é hoje. [...] A gente tem medo que ela tenha uma recaída e não consiga voltar ao que ela é hoje.” (Família 19)

“É então... Ah, eu me preocupo com ele, porque né, igual a mim to falando, né, quando eu morrer, fico mais preocupada porque num tem ninguém pra trata dele, eu fico com medo assim, né, de num te ninguém pra trata dele. E de num trata igual a mim, porque, igual a mim num vai mesmo trata não, né. Aí eu fico mais preocupada ainda. Aí eu num durmo de noite por isso, porque eu fico preocupada. Por isso que eu num durmo de noite." (Família 09)

“Ah, isso eu fico meio com medo, sabe assim, medo assim, dele perde meu pai, porque meu pai que cuida dele, aí pra onde que ele vai esse menino? [...] Então eu penso assim, quando meu pai falece e num pude cuida mais dele, eu num sei o que vai se do futuro dele, eu tenho medo, né [...]”" (Família 10)

“Eu penso assim, o dia de amanha, que eu faltar, que eu não tiver mais aqui, eu penso neles, como é que eles vão se virar, né. Que eu, espero que eles se, eu penso no dia de amanha deles ficar sozinhos, como que eles vão se virar, né. Porque eles não trabalham, [...]" (Família 23)

O confronto direto com o familiar doente também passou a ser evitado. Isto ocorreu para evitar que o máximo que aborrecimentos fossem gerados ao doente e assim, um possível estímulo aos sintomas da doença, principalmente a agressividade.

"Evita de falar com ela coisas que causem algum aborrecimento, evitam estar contrariando ela. [...] Principalmente minha mãe. Não digo meu pai, mas minha mãe. Entre aspas, mima demais. É, ela responde, ela xinga, e assim minha mãe, com esse medo que ela tem, acho que [...] Que ela pode ter uma crise novamente, então assim, ela abusa um pouquinho disso. [...] Mesmo que inconscientemente.” (Família 19) 
“A irmã dela procura impedir bastante algo que possa contrariar a minha filha doente. A irmã não bate de frente, ela procura contornar pra não deixar a minha filha doente nervosa.” (Família 26)

“[...] que minha menina fala, reclama que a gente fica na mão dele por causa do medo, se ele fala não, é não. Enfim, ele que sempre dá a ultima cartada, se ele não quer sair, ninguém sai, se ele quer, todo mundo sai.” (Família 02)

Novos rearranjos são feitos devido disputas, ciúmes, super-envolvimento e redefinição de papeis.

“Ah, eu não sei, ele fala assim que às vezes eu dou mais atenção pro pai dele, sabe. É, as vezes, é que meu marido não gosta, ele gosta que eu coloque a mesa, assim, eu coloco comida pra ele no prato, sempre, então o $\boldsymbol{B}$ fala assim, "a senhora tem que fazer igual comigo”, sabe. É aquele tipo de coisa, aqueles ciuminhos bestas, assim.” (Família 13)”

“Minha mãe tenta sempre deixar a minha irmã bem, querer ajudar a minha irmã, agradar ela, né. Minha mãe faz tudo pela minha irmã. Lava, passa, tem, faz de tudo pra ela, mas a minha irmã tem hora que ela muda. Ela muda o jeito dela.” (Família 05)

Assim a família vai dando seqüência a sua trajetória com a esperança da melhora do doente, e com o medo de uma nova crise. Tentando se equilibrar nestas duas posições a família segue em frente após os primeiros anos de adoecimento.

\section{Discussão}

A preocupação com o doente e suas ações, com a manutenção financeira e dos relacionamentos sociais de todo o grupo, a melhora do quadro e da qualidade de vida do doente e da família, o aprendizado de conviver com a doença e o futuro de ambos, doente e família, são preocupações presentes na fase nomeada de Seguindo em Frente.

Harden (2005) e Stein e Wemmerus (2001) que também encontraram um momento semelhante ao descrito na fase Seguindo em Frente. Eles argumentam que uma das dificuldades de portador de esquizofrenia é a dificuldade de assumir responsabilidades, principalmente no inicio da doença. Assim, há a necessidades de outros membros da família 
assumir ou darem suporte às responsabilidades que o seu familiar doente não está conseguindo assumir naquele momento.

Tanto neste estudo como em estudos existentes, os familiares dividem funções de acordo com o que cada membro é capaz de assumir. O cuidador principal foi estabelecido e, em um segundo momento, ocorre à inclusão de outras pessoas no cuidado. Ainda vários sentimentos de duvida, ciúmes, disputas e medos são percebidos e vivenciados. Alianças são desfeitas e refeitas constantemente, o que interfere diretamente no desenvolvimento funcional da família (PEJLERT, 2001; STEIN; WEMMERUS, 2001).

Nesta fase e em fases similares de estudos já existentes, percebemos que a família sente-se obrigada a assumir o cuidado do seu familiar doente, promovendo seu bem-estar, proteção e cuidado profissional. Tentam proporcionar ao seu familiar o melhor cuidado possível, na tentativa de evitar novas crises (MILLIKEN; NORTHCOTT, 2003).

Em estudo realizado por Romagnoli (2006) na região metropolitana de Belo Horizonte, com o objetivo de entender as mudanças ocorridas no processo de vida da família após o surgimento da doença mental, todas as famílias acabam estruturando o seu cotidiano em torno da doença mental.

Nesta pesquisa identificamos dois sentimentos importantes na fase atual que as famílias estão vivendo, que é a fase seguindo em frente. A esperança e o medo. A esperança movimenta a família no sentido de buscar maior autonomia e independência do doente, enquanto que o medo faz com que ela esteja sempre vigilante do comportamento do doente. 
Quando o doente começa a apresentar mudanças de comportamento, como sinais e sintomas psicóticos, a família percebe que algo está errado, mas não tem a preocupação em procurar o serviço de saúde. Ela justifica como atitudes do processo de transição da fase infantil para a adulta. Após o primeiro episódio psicótico, ocorre um choque em todo o núcleo familiar. Sentimentos intensos são vivenciados. Com o estabelecimento do diagnóstico e o inicio do tratamento, ocorre uma melhora e a família vivencia sentimentos de esperança e medo. Esperança que o doente melhore e medo de uma nova crise como a vivenciada na fase anterior. Após os cinco primeiros anos a família segue em frente estimulando a independência e autonomia de seu doente e vigiando seus comportamentos.

A família percebe também a necessidade de reorganização, para que todos os membros do grupo possam assegurar suas necessidades também. Papeis são restabelecidos e outros novos são assumidos, responsabilidades são delegadas e divididas. Além do contínuo processo de aprendizagem em conviver com um membro com esquizofrenia e as demandas por ele geradas.

Todas as fases apresentadas neste projeto são ricas e podem ser mais exploradas. A primeira fase, "percebendo a mudança”, chama a atenção pela confusão entre os sintomas iniciais do adoecimento e as características da adolescência. A dificuldade do diagnóstico faz com que ocorrência do primeiro surto seja intensa e agressiva, tanto para a família como para o doente. Outro ponto importante a se trabalhar é a questão da falta de apoio do sistema de saúde nos primeiros cinco anos. Ela faz com que as famílias vivam exclusivamente para o doente. Talvez um apoio contínuo e educativo desde o inicio da doença diminua o impacto na família, suas transformações sejam mais amenas e ela consiga, assim, proporcionar se tornar um ambiente de qualidade para seus membros e seu doente.

Outro aprendizado deste estudo foi à dificuldade encontrada em conseguir reunir um grupo maior de familiares para a participação na pesquisa. Como uma única pessoa normalmente fica responsável pelas atividades diárias do doente, e a pesquisa foi realizada no serviço de atendimento do familiar doente, a proposta inicial de trabalhar-se com um grupo de pelo menos dois familiares foram atingidos em apenas duas entrevistas.

Pesquisas internacionais têm uma maior amostra de sujeitos. Porém elas são realizadas com critérios mais gerais e em sua maioria por grupos de pesquisas que abrangem diferentes serviços de localidades diferentes. Considerando que, por ser uma pesquisa qualitativa, bem estruturada, com delineamento de critérios bem definidos, com um grupo a ser estudado restrito, em dois serviços de saúde de uma única cidade de aproximadamente 600 mil habitantes, acreditamos que o número de participantes da pesquisa pode ser considerado capaz 
para a validação dos resultados aqui encontrados. Lembrando-se que resultados de uma pesquisa qualitativa não podem ser generalizados para uma grande população, mas caracterizam bem a população estudas e assim subsidiam outros estudos detalhados de outras populações. 
AMERICAN PSYCHIATRIC ASSOCIATION. Diagnostic and statistical manual of mental disorders. 4th ed. Washington (DC): American Psychiatric Association, 1994. p. 1-555.

ASBRING, P. Chronic illness - a disruption in life: identity-transformation among women with chronic fatigue syndrome and fibromyalgia. Journal of Advanced Nursing, v. 34, n. 3, p. 312-319, 2001.

ASSUMPÇÃO JR, F.B.; KUCZYNSKI, E. Adolescência: Normal e Patológica. São Paulo:Lemos Editorial, 1999. 239p.

BOSS, P. Family Stress Management. California: SAGE Publications, 1988. 160 p. (Family Studies Text Series, 8)

CASSIANI, S. de B.; CALIRI, M. H. L.; PELÁ, N. T. R. A teoria fundamentada nos dados como abordagem da pesquisa interpretativa. Rev. Latino-am. Enfermagem, v. 4, n. 3, p. 7588, dez 1996.

CERVENY, C. M. O.; BERTHOUD, C. M. E. Visitando a família ao longo do Ciclo Vital. São Paulo: Casa do Psicólogo, 2002. 199 p.

CHESLA, C. A. Nursing science and chronic illness: articulating suffering and possibility in family life. Journal of Family Nursing, v. 11, n. 4, p. 371-387, 2005.

CONN, V. A visão da família sobre o continuum do atendimento. In: STUART, G. W.; LARAIA, M. T. Enfermagem psiquiátrica - princípios e prática. Porto Alegre: ArtMed Editora, 2001. p. 296 - 302.

DUHAMEL, F.; TALBOT, L. R. A constructivist evaluation of family systems nursing interventions with families experiencing cardiovascular and cerebrovascular illness. Journal of Family Nursing, v. 10, n. 1, 2004.

ELDER JUNIOR, G. H.; JOHNSON, M. K.; CROSNOE, R. The emergence and development of life course theory. In: MORTIMER, J. T.; SHANAHAN, M. J. Handbook of the life course. New York:Springer, 2003. p. 3-19.

GALERA, S. A. F. Avaliação construtivista de uma intervenção de enfermagem junto a famílias que tem entre seus membros um portador de esquizofrenia. 2002. 164f. Tese (Doutorado em Enfermagem Psiquiátrica) - Escola de Enfermagem de Ribeirão Preto, Universidade de São Paulo, São Paulo, 2002. 
GALERA, S. A. F.; LUIS, M. A. V. Principais conceitos da abordagem sistêmica em cuidados de enfermagem ao indivíduo e sua família. Revista da Escola de Enfermagem da USP, v. 36, n. 2, p. 141-147, 2002.

GIACON, B. C. C.; GALERA, S. A. F. Primeiro episódio da esquizofrenia e assistência de enfermagem. Revista da Escola de Enfermagem da USP, v. 40, n. 2, p. 286-291, 2006.

GLASER, B.; STRAUSS, A. The discovery of grounded theory. New York:Aldene de Gruyter, 1997. 271p.

HARDEN, J. Parenting a young person with mental health problems: temporal disruption and reconstruction. Sociology of Health \& Illness, v. 27, n. 3, p. 351-371, 2005.

HARPHAM, T. Saúde mental, desenvolvimento e pobreza. Revista Brasileira de Psiquiatria, v. 22, n. 3, p. 103-103, set 2000.

HEATH H.; COWLEY, S. Developing a grounded theory approach: a comparison of Glaser and Strauss. International Journal of Nursing Studies, v. 41, p. 141-150, 2004.

JUNGBAUER, J.; STELLING, K.; DIETRICH, S.; ANGERMEYER, M. C. Schizophrenia: problems of separation in families. Journal of Advanced Nursing, v. 47, n. 6, p. 605-613, 2004.

JUNGBAUER, J.; WITTMUND, B; DIETRICH, S.; ANGERMEYER M. C. Subjective Burden Over 12 Months in Parents of Patients Whith Schizophrenia. Archives of Psychiatric Nursing, v. XVII, n. 3, p. 126-134, jun 2003.

KANE, J. M.; LIEBERMAN, J. A. Maintenance pharmacotherapy in schizophrenia. In: MELTZER, H. Y. Organizador Psychopharmacology: the third generation of progress. New York: Raven Press, 1987. p.1103-1109.

KARP, D. A.; TANARUGSACHOCK, V. Mental Illness, Caregiving, and Emotion Management. Qualitative Health Research, v. 10, n. 1, p. 06-25, 2000.

MARI, J. J.; LEITÃO, R. J. A epidemiologia da esquizofrenia. Revista Brasileira de Psiquiatria, v.22, p. 15-17, 2000. Suplemento I. 
MAUHLBAUER, A. S. Navigating the Storm of Mental Illness: Phases in the Family's Journey. Qualitative Health Research, v. 12, n. 8, p. 1076-1092, oct 2002.

MAYAN, M. Una introducción a los métodos cualitativos. Modulo de entrenamiento para estudiantes y profesionales, International Institute for Qualitative Methodology. http://www.ualberta.ca/ iiqm//pdfs/introduction.pdf. 2001.

MEIJEL, B.V.; GAGA M.V.; KAHN R.S.; GRYPDONCK M. The practice of early recognition and early intervention to prevent psychotic relapse in patients with schizophrenia: an exploratory study Part 2. Journal of Psychiatric and Mental Health Nursing, v. 9, p. 357-363, 2002.

MILLIKEN, P. J. Disenfranchised mothers: caring for an adult child with schizophrenia. Health Care for Women International, v. 22, p. 149-166, 2001.

MILLIKEN, P. J.; NORTHCOTT, H. C. Redefining Parental Identity: Caregiving and Schizophrenia. Qualitative Health Research, v. 13, n. 1, p. 100-113, 2003.

MORIARTY, H. J. Key issues in the family research process: strategies for nurse research. Advanced Nursing Science, v. 12, n. 3, p. 1-14, 1990.

NICO, L. S. et al. A grounded theory como abordagem metodológica para pesquisas qualitativas em odontologia. Ciência \& Saúde Coletiva, v. 12, n. 3, p. 789-797, 2007.

OLIVEIRA, R. M. P.; LOYOLA C. M. Família do paciente psiquiátrico: o retrato de uma ilustre desconhecida. Acta Scientiarum Health Sciences, v. 26, n. 1, p. 213-222, 2004.

ORGANIZAÇÃO MUNDIAL DA SAÚDE. Classificação estatística Internacional de doenças e problemas relacionados à saúde. São Paulo: EDUSP, 1993. p. 325-332.

PEJLERT, A. Being a parent of an adult son or daughter with severe mental illness receiving professional care: parents' narratives. Health and Social Care in the Community, v. 9, n. 4, p. 194-204, 2001.

PETTENGILL, M. A. M.; ANGELO, M. Vulnerabilidade da família: desenvolvimento do conceito. Rev. Latino-am. Enfermagem, v. 13, n. 6, p. 982-988, 2005. 
ROBINSON, C. A.. Unifying distinctions for nursing research with persons and families. Journal of Family Nursing, v. 1, p.8-29, 1995.

SAUNDERS, J. Walking a mile in their shoes: symbolic interactionism for families living with severe mental illness. Journal of Psychosocial Nursing, v. 35, n. 6, p. 8-13, 1997.

SCALON, A. Psychiatric nurses perceptions of the constituents of the therapeutic relationship: a grounded theory study. Journal of Psychiatric and Mental Health Nursing, v. 13, p. 319-329, 2006.

SCHNEIDER, J. F. O cuidado e a família do esquizofrênico. Mundo Saúde, São Paulo, v. 24, n. 4, p. 284-290, jul/ago 2000.

SMITH, G. C. Predictors of the Stage of Residential Planning Among Aging Families of Adults with Severe Mental Ilness. Psychiatry Services, v. 55, n. 7, p. 804-810, jul 2004.

STEIN, C. H.; WEMMERUS, V. A. Searching for a normal life: personal accounts of adults with schizophrenia, their parents and well-siblings. American Journal of Community Psychology, v. 29, n. 5, p. 725-746, oct 2001.

STUART, M. E. An analysis of the concept of family. In: WHALL, A. L.; FAWCETT, J. Family theory development in nursing: State of the science and art. Philadelphia:FA Davi, 1991. p. 31-42.

TESCHINSKY, U. Living with schizophrenia: The family illness experience. Issues in Mental Health Nursing, v. 21, p. 387-396, 2000.

TOSTES, L. R. M.; MORAES L. R. N. Esquizofrenia: curso, evolução e prognóstico. Jornal Brasileiro de Psiquiatria, v. 38, n. 4, p. 233-9, jul/ago 1989.

VAUGHAN-COLE, B. Family nursing research. In: VAUGHAN-COLE, B. et al. Family nursing practice. Philadelphia:Saunders, 1997. p. 347-364.

WERNET, M.; ÂNGELO, M. Mobilizando-se para a família: dando um novo sentido à família e ao cuidar. Rev Esc Enferm USP, v. 37, n. 1, p. 19-25, 2003. 
WRIGHT, L. M.; LEAHEY, M. Enfermeiras e famílias - um guia para a avaliação e intervenção na família. São Paulo:Rocca, 2002. 328 p.

YAMASHITA, M. Family coping with mental illness: a comparative study. Journal of Psychiatric and Mental Health Nursing, v. 5, p. 515-523, 1998. 
ANEXOS 
ANEXO A

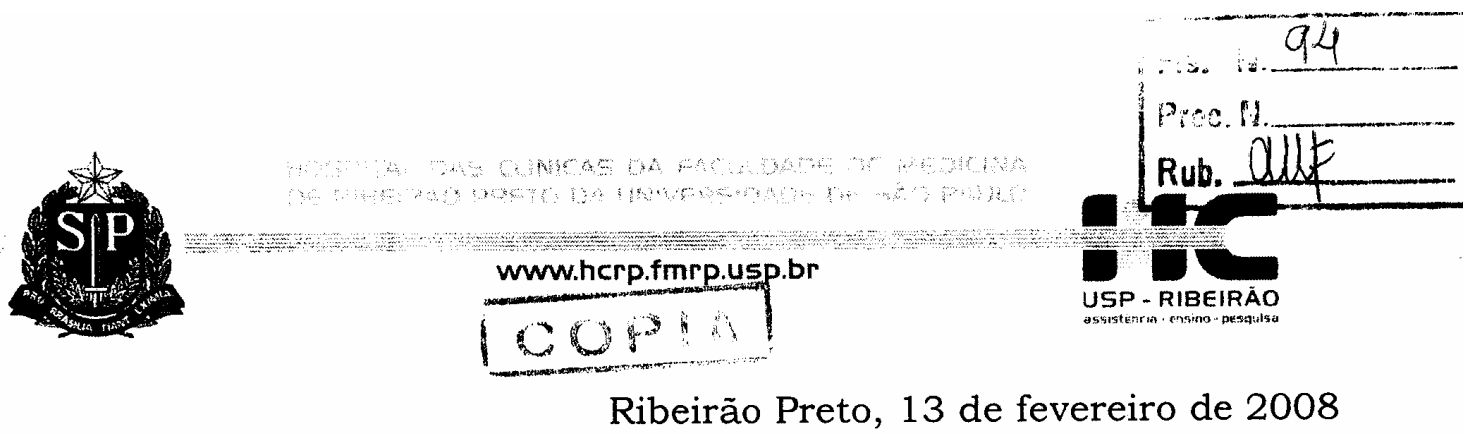

Ofício $n^{\circ} 421 / 2008$

$\mathrm{CEP} / \mathrm{MGV}$

\section{Prezada Senhora,}

O trabalho intitulado "ADAPTAÇÃo FAMILIAR NOS PRIMEIROS CINCO ANOS DE DIAGNÓSTICO DE ESQUIZOFRENIA", foi analisado pelo Comitê de Ética em Pesquisa, em sua $260^{a}$ Reunião Ordinária realizada em $11 / 02 / 2008$, e enquadrado na categoria: APROVADO, bem como o Termo de Consentimento Livre e Esclarecido, de acordo com o Processo HCRP $\mathrm{n}^{\circ} 9800 / 2007$.

Lembramos que devem ser encaminhados a este CEP relatórios semestrais e relatório final da pesquisa.

Atenciosamente.

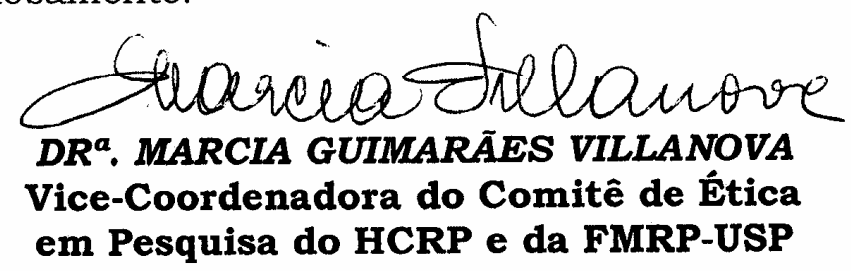

Ilustrissima Senhora

ENF ${ }^{2}$. BIANCA CRISTINA CICCONE GIACON

PROF $^{a}$. DR ${ }^{a}$. SUELI APARECIDA FRARI GALERA(Orientadora)

Escola de Enfermagem de Ribeirão Preto-USP 
APÊNDICES 


\section{APÊNDICE A - Roteiro da entrevista}

O adoecimento de um membro da família com esquizofrenia provoca mudanças na trajetória de vida que vinha sendo construída. A doença mental causa uma mudança na vida do doente e de sua família.

1-) Como era composta a família antes do adoecimento de ? Como era o relacionamento entre os membros e entre a família e a sociedade? (Passado)

2-) Qual a sua percepção da sua família após o adoecimento de ? Gostaria que você contasse como é sua família agora, como é composta e o quê mudou após o adoecimento de ? (Presente)

4-) A doença mental afetou sua família? Como?

5-) Ocorreram mudanças? Quais?

6-) Como vocês tem se organizado frente a situação de adoecimento de ?

7-) Qual as expectativas e sentimentos de sua família para o futuro? 


\section{APÊNDICE B - Questionário Sócio demográfico}

A) Identificação da família:

Iniciais do paciente:

Idade:

Sexo: Estado civil:

Escolaridade: Ocupação:

B) Identificação do familiar

Grau de parentesco:

Nível de escolaridade:

Idade: Sexo:

Composição familiar:

\begin{tabular}{|l|l|l|l|l|}
\hline Nome & $\begin{array}{l}\text { Grau de } \\
\text { parentesco }\end{array}$ & Idade & Escolaridade & Renda \\
\hline & & & & \\
\hline & & & & \\
\hline & & & & \\
\hline & & & & \\
\hline
\end{tabular}

Renda familiar total:

Número de cômodos na casa:

Madeira ( ) Alvenaria ( )

Própria ( ) Alugada ( )

Divide quintal com outros: 


\title{
APÊNDICE C - Termo de Consentimento Livre e Esclarecido - Paciente
}

\author{
Pesquisadora: Bianca Cristina Ciccone Giacon
}

Telefone: (16) 3963-3368

e-mail: biagiacon@gmail.com

Orientadora: Professora Doutora Sueli Aparecida Frari Galera

Escola de Enfermagem de Ribeirão Preto - Universidade de São Paulo

Av. Bandeirantes 3900 - Campus Universitário. Ribeirão Preto - Brasil

Telefone: (16) 3602-3408

e-mail: sugalera@eerp.usp.br

Meu nome é Bianca Cristina Ciccone Giacon, sou aluna de pós-graduação, nível mestrado, da Escola de Enfermagem de Ribeirão Preto da Universidade de São Paulo, e estou estudando como a família do portador de esquizofrenia vai se adaptando após o adoecimento de um de seus membros. Gostaria de pedir sua permissão para conversar com dois dos seus familiares, pois considero que eles são pessoas importantes para contar sobre esta experiência.

O nome do meu trabalho de pesquisa é Adaptação familiar nos primeiros cinco anos de diagnóstico de esquizofrenia. Se você concordar que eu entreviste seus familiares eu vou marcar duas entrevistas com eles. Cada entrevista deve durar mais ou menos uma ou duas horas, e será realizada no serviço onde você faz tratamento ou em outro lugar que os seus familiares indicarem.

\section{Liberdade de escolha e direito de recusar:}

Você pode decidir se quer ou não que seus familiares participem do estudo. Você pode também decidir parar de participar, basta informar a pesquisadora. A decisão de não participar da pesquisa não afeta o atendimento e nem o seu tratamento.

\section{Riscos e Benefícios:}

Pensamos que não existem riscos em participar do estudo. O único benefício pode ser a chance de discutir assuntos de interesse de toda a família.

\section{Privacidade e 0 aspecto confidencial:}

Você é livre para decidir se quer ou não participar do estudo. Sua decisão não interfere no seu tratamento. As entrevistas com seus familiares serão gravadas em fita K7. A 
pesquisadora vai escrever a entrevista gravada palavra por palavra. Somente a pesquisadora vai ouvir a fita. A equipe do serviço onde você faz tratamento não vai ouvir a fita e não vai ler a entrevista. Se você quiser você poderá ler as entrevistas. Basta solicitar.

Toda informação dada nas entrevistas será mantida em segredo, exceto quanto se tratar de assunto que o código profissional, de ética ou legal requer que seja comunicado. Por exemplo, se o familiar contar sobre alguma situação de risco para você, para eles, ou para terceiros eu tenho a obrigação de falar com algum profissional do serviço sobre isto.

\section{Para entrar em Contato:}

Para qualquer esclarecimento, você poderá entrar em contato com a pesquisadora Bianca Cristina Ciccone Giacon pelo telefone (16)3963-3368, ou com a orientadora do estudo, a Prof ${ }^{a}$ Dr $^{\text {a }}$ Sueli Ap. Frari Galera na Escola de Enfermagem de Ribeirão Preto - USP ou pelo telefone (16) 3602-3408.

\section{TERMO DE CONSENTIMENTO LIVRE E ESCLARECIDO - Paciente}

$\mathrm{Eu}$, RG abaixo assinado, após ter recebido as informações da pesquisadora Bianca Cristina Ciccone Giacon sobre sua pesquisa intitulada Adaptação familiar nos primeiros cinco anos de diagnóstico de esquizofrenia e que tem como objetivo conhecer como a família vai se organizando após o adoecimento de um de seus membros, concordo que meus familiares sejam entrevistados e que a pesquisadora use o gravador para registrar a entrevista. Confirmo ter recebido as informações sobre a pesquisa a ser desenvolvida, e estou ciente sobre meus direitos abaixo relacionados:

1. A garantia de receber resposta a qualquer pergunta ou esclarecimento a dúvidas acerca dos procedimentos, riscos, benefícios e outros relacionados à pesquisa.

2. A liberdade de retirar meu consentimento a qualquer momento e deixar de participar do estudo, sem que isso traga qualquer prejuízo para o meu tratamento.

3. A segurança de que serão preservadas a identidade e privacidade dos entrevistados.

4. O compromisso de me valer da legislação em caso de dano.

5. A garantia de que não haverá riscos, desconforto ou gastos de qualquer natureza. 
6. A garantia de seguir todas as exigências que constam na Resolução $n^{\circ} 196$, de 10 de outubro de 1996, que regulamenta o desenvolvimento de pesquisas envolvendo seres humanos.

Esclareço que em caso de dúvida, fui orientado a procurar a pesquisadora Bianca Cristina Ciccone Giacon através do telefone (16) 3963-3368 ou a professora Sueli Ap. Frari Galera na Escola de Enfermagem de Ribeirão Preto - USP ou pelo telefone (16) 3602-3408.

Declaro que tenho conhecimento dos direitos acima descritos, e concordo que a pesquisadora entre em contato com meus familiares, realizado pela pesquisadora que subscreve este termo de consentimento.

De acordo,

Ribeirão Preto, de de

Participante da pesquisa Responsável pela pesquisa Uma cópia deste termo de consentimento deverá ser fornecida ao participante. 


\section{APÊNDICE D - Termo de Consentimento Livre e Esclarecido - Familiar}

\section{CONVITE}

Pesquisadora: Bianca Cristina Ciccone Giacon

Telefone: (16) 3963-3368

e-mail: biagiacon@gmail.com

Orientadora: Professora Doutora Sueli Aparecida Frari Galera

Escola de Enfermagem de Ribeirão Preto - Universidade de São Paulo

Av. Bandeirantes 3900 - Campus Universitário. Ribeirão Preto - Brasil

Telefone: (16) 3602-3408

e-mail: sugalera@eerp.usp.br

Meu nome é Bianca Cristina Ciccone Giacon, sou aluna de pós-graduação, nível mestrado, da Escola de Enfermagem de Ribeirão Preto da Universidade de São Paulo, e estou estudando como a família do portador de esquizofrenia vai se adaptando após o adoecimento de um de seus membros. Por isso, considero que você, sendo familiar de uma pessoa que sofre de esquizofrenia é uma pessoa importante para contar sobre esta experiência.

O nome do meu trabalho de pesquisa é Adaptação familiar nos primeiros cinco anos de diagnóstico de esquizofrenia. Se você se interessar em participar deste estudo, poderíamos marcar dois encontros. Cada entrevista deve durar mais ou menos uma ou duas horas, e será realizada no serviço em que seu familiar é assistido ou em outro lugar que vocês indicarem.

\section{Liberdade de escolha e direito de recusar:}

Você não precisa responder nenhuma pergunta que não queira. Você pode decidir se quer ou não participar do estudo. Você pode também decidir parar de participar, basta informar a pesquisadora. A decisão de não participar da pesquisa não afeta o atendimento e nem o tratamento do seu familiar.

\section{Riscos e Benefícios:}

Pensamos que não existem riscos em participar no estudo. O único benefício pode ser a chance de discutir assuntos de seu interesse e de toda a família. Por favor, não se sinta pressionado para falar sobre alguma coisa que você não deseja falar. 


\section{Privacidade e o aspecto confidencial:}

Você é livre para decidir se quer ou não participar das entrevistas, que serão gravadas. Sua decisão não interfere no tratamento do seu familiar. Nossa conversa será gravada em fita K7. A pesquisadora vai escrever a entrevista gravada palavra por palavra. Somente a pesquisadora vai ouvir a fita. A equipe do serviço no qual ele é assistido não vai ouvir a fita e não vai ler a entrevista. Porém, se o seu familiar quiser ler a entrevista ele terá permissão.

Toda informação que você der será mantida em segredo, exceto quanto se tratar de assunto que o código profissional, de ética ou legal requer que seja comunicado. Por exemplo, se o paciente estiver envolvido em algum tipo de risco para ele, para algum membro da família, ou terceiros eu tenho a obrigação de falar com algum profissional do serviço sobre isto.

\section{Para entrar em Contato:}

Para qualquer esclarecimento, você poderá entrar em contato com a pesquisadora Bianca Cristina Ciccone Giacon pelo telefone (16)3963-3368 ou com a professora Sueli Ap. Frari Galera na Escola de Enfermagem de Ribeirão Preto - USP ou pelo telefone (16) 36023408.

\section{TERMO DE CONSENTIMENTO LIVRE E ESCLARECIDO - Familiar}

$\mathrm{Eu}$,

RG abaixo assinado, após ter recebido as informações

da pesquisadora Bianca Cristina Ciccone Giacon sobre sua pesquisa intitulada Adaptação familiar nos primeiros cinco anos de diagnóstico de esquizofrenia e que tem como objetivo conhecer como a família vai se organizando após o adoecimento de um de seus membros, concordo em ser entrevistado e que a pesquisadora use o gravador para registrar a entrevista. Confirmo ter recebido as informações sobre a pesquisa a ser desenvolvida, e estou ciente sobre meus direitos abaixo relacionados:

1. A garantia de receber resposta a qualquer pergunta ou esclarecimento a dúvidas acerca dos procedimentos, riscos, benefícios e outros relacionados à pesquisa.

2. A liberdade de retirar meu consentimento a qualquer momento e deixar de participar do estudo, sem que isso traga qualquer prejuízo para o entrevistado. 
3. A segurança de que serão preservadas a identidade e privacidade do entrevistado.

4. O compromisso de me valer da legislação em caso de dano.

5. A garantia de que não haverá riscos e nem desconfortos, gastos de qualquer natureza.

6. A garantia de seguir todas as exigências que constam na Resolução nº196, de 10 de outubro de 1996, que regulamenta o desenvolvimento de pesquisas envolvendo seres humanos.

Esclareço que em caso de dúvida, fui orientado a procurar a pesquisadora Bianca Cristina Ciccone Giacon através do telefone (16) 3963-3368 ou a professora Sueli Ap. Frari Galera na Escola de Enfermagem de Ribeirão Preto - USP ou pelo telefone (16) 3602-3408.

Declaro que tenho conhecimento dos direitos acima descritos, e consinto em participar deste estudo, realizado pela pesquisadora que subscreve este termo de consentimento.

De acordo,

Ribeirão Preto, de de 